\title{
Demand for education in the five countries of the South African Customs Union - Projections and implications
}

\author{
SERVAAS VAN DER BERG \\ MARIZANNE KNOESEN
}

\section{Stellenbosch Economic Working Papers: WP20/2018}

www.ekon.sun.ac.za/wpapers/2018/wp202018

December 2018

KEYWORDS: economic development, demand for education, enrolment projections, South African Customs Union area

JEL: I20, I25, J24

\section{ReSEP (Research on Socio-Economic Policy)}

http://resep.sun.ac.za

DEPARTMENT OF ECONOMICS

UNIVERSITY OF STELLENBOSCH

SOUTH AFRICA

A WORKING PAPER OF THE DEPARTMENT OF ECONOMICS AND THE BUREAU FOR ECONOMIC RESEARCH AT THE UNIVERSITY OF STELLENBOSCH 


\title{
Demand for education in the five countries of the South African Customs Union - Projections and implications ${ }^{1}$
}

\author{
Servaas van der Berg² and Marizanne Knoesen ${ }^{3}$
}

\begin{abstract}
Demand for education rises with the level of economic development and over time. Censuses and surveys provide an approximation of realized demand for education for different birth cohorts over a long time span across countries and grades. Of the five SACU countries, Botswana, Lesotho, Namibia, South Africa, and Swaziland, all except Namibia have already achieved school participation rates above $90 \%$ up to age 14 . However, grade achievement is not equally impressive, due to high repetition. The projections of grade completion reported here incorporate UN Population Division demographic projections and assume that completion rates will asymptotically approach an upper limit. Assuming that repetition will stabilize allows estimation of enrolment. Future enrolment growth will slow due to slower growth of the schoolaged population and because enrolment is already high. Demand for new teachers, however, should slow less, as the age structure of the current teaching personnel implies high levels of retirement. Tertiary enrolment will be constrained by the supply of tertiary places. To meet young people's rising labor market expectations requires strong economic growth and labor absorption, improved education quality, and a focus on teaching appropriate skills. International tests show that education quality is weak in the SACU countries. Providing specialized tertiary and technical training for the four small SACU economies will require collaborative efforts.
\end{abstract}

\footnotetext{
${ }^{1}$ This paper was originally produced for a World Bank research project on the Demographic Dividend for SACU countries. Views expressed are our own.

2 Servaas van der Berg is a researchers at ReSEP (Research on Socio-Economic Policy), Stellenbosch University. Postal address: Department of Economics, Schumann Building, De Beer Street, Stellenbosch University, Stellenbosch 7600. Email: svdb@sun.ac.za

${ }^{3}$ Marizanne Knoesen is an independent researcher. Postal address: PO Box 12137, Die Boord, Stellenbosch 7613. Email: marizanneknoesen@gmail.com
} 
Education has a number of properties which make the analysis of the demand for it both interesting and complex... It is a consumption good and a capital good, i.e., although much of the expenditure is justified in terms of the effects on the individual's income in the future, many of the activities of educational institutions are primarily justifiable in terms of their immediate consumption benefits. Moreover, education affects individuals' future incomes. (Stiglitz 1974: 349)

\section{Introduction: The demand for education}

The demand for education is influenced by its costs and benefits, as perceived by those who decide whether to send their children to school. These costs and benefits, and perceptions of their magnitude, vary in the course of a country's development and therefore influence the demand for education.

One factor that affects the benefits of education is how education is rewarded in the labor market, in other words the returns to education. The level and nature of a country's economic development influence the demand for skills. Thus, where subsistence farming is dominant, the demand for skills will be small, but as the country develops, the demand will grow and getting an education will become more attractive.

Parental experience of education and its benefits affects the way education is perceived. Investment in children's education may seem irrational, for example, to subsistence farming communities with a big demand for labor, and even more so where quality of the education is weak.

Parental interest in children's education is important for school attendance. Illiterate or poorly educated parents will have little understanding of the benefits education can bring. In Namibia, for instance, census figures indicate that $54 \%$ of adults in rural areas over 20 years of age cannot read or write, as against $23 \%$ in urban areas, so perception of the benefits of education is likely to be low in the country's rural areas.

As a country's economy develops and the demand for skills increases, the returns to investment in education also tend to increase. In South Africa, for instance, the demand for high-level skills has meant that a university graduate earns about $2 \frac{1}{2}$ times as much as a school leaver who completed Grade 12, controlling for other variables. However, a rapid rise in wages, as for instance experienced by Vietnam in the 1990s, can temporarily decrease the demand for higher levels of education, as the higher wages increase the opportunity cost of further education and it becomes more attractive to start working early rather than study further (Glewwe and Jacoby 2004).

Education has both direct and indirect costs. In most developing countries, the Education for All initiative has at least brought free primary education, as far as the direct costs (i.e. school fees) are concerned. That the direct costs of education may have held back the demand for education is apparent from the rapid increases in school numbers in extremely poor countries where school fees have been abolished, notably Malawi (Mussa, 2009) and Mozambique (Mussa, 2009; Da Maia, 2012; Spaull and Taylor, 2015).

But the indirect costs of education, for example for uniforms, transport, boarding school fees, books, and stationery, can also be high, and may make it difficult for many poor parents to afford their children's education.

Besides these explicit costs, there are also opportunity costs attached to education. In many households, children who are old enough to help with household chores or care for their elders are required to do so. Cultural beliefs, such as the view that boys should work in the fields and 
girls should run the household, may reduce the demand for education. The incidence of child labor is more prevalent among poor families and intensifies during the main farming season. Poverty and a low value attached to education can combine to force children into the labor market. Especially for older children, the opportunity costs of education can be high: for many children, staying at school another year or two when they are old enough to find a job is not an option.

\section{Patterns of demand for education}

Economic development is closely associated with economic, social, and technological changes. Hollis Chenery used cross-country patterns of development to investigate how structural change is associated with growth and development, as measured by the log of per capita income (Chenery and Syrquin, 1975; Chenery, 1979). Chenery assumed that such cross-country patterns could best be captured by a logistic or S-curve, as most social indicators, such as fertility rate, life expectancy, or proportion of population at school, move between a low and a high asymptote. ${ }^{4}$ Patrinos and Psacharopoulos (2011: 4) also suggest using such an S-shaped pattern to reflect trends in educational development over time, but they use time rather than level of development on the x-axis. As Chenery (1979) and Chenery and Syrquin (1975) acknowledged, these curves did not necessarily reflect countries' development paths but simply the patterns created by historical development paths. It is very likely that these curves would shift over time.

The demand for education is likely to follow a similar pattern, but with both the cross-country patterns and the shifts in these patterns reflecting changes over time. For Chenery (1979), educational expansion was part of what he called "accumulation processes".

Worldwide, the demand for education has grown. Looking at today's developed countries, we find that their demand for education in the period before World War II was lower than the demand for education is today in countries that are poorer than those developed countries were then.

Figure 1 shows how demand for education increases not only with the level of development but also over time. Using data from the World Data Bank and the UNESCO Institute of Statistics (UIS), the figure shows transition rates from primary to secondary school across countries, i.e. the proportion of children who completed primary school and continued to secondary school in 1990 and 2012. There was an upward shift over time that did not simply reflect rising per capita income (which in Figures $1 \mathrm{~A}, \mathrm{~B}$ and $\mathrm{C}$ would simply have implied a rightward movement along the graph). Put differently, though the transition rates tend to rise with economic development, changes over time also affect patterns. Figure $1 \mathrm{C}$, which shows the locally weighted regression curves (LOESS curves) for the two years, shows how the curve has shifted upwards: the transition rate from primary to secondary school has increased more than one would expect, given the increase in the level of development.

\footnotetext{
${ }^{4}$ As most countries have moved far beyond the initial asymptote, Chenery fitted a quadratic regression, to approximate the shape of the logistic curve for the relevant part of the curve.
} 
Figure 1 : Transition rates from primary to secondary school, 1990 and 2012

A: 1990

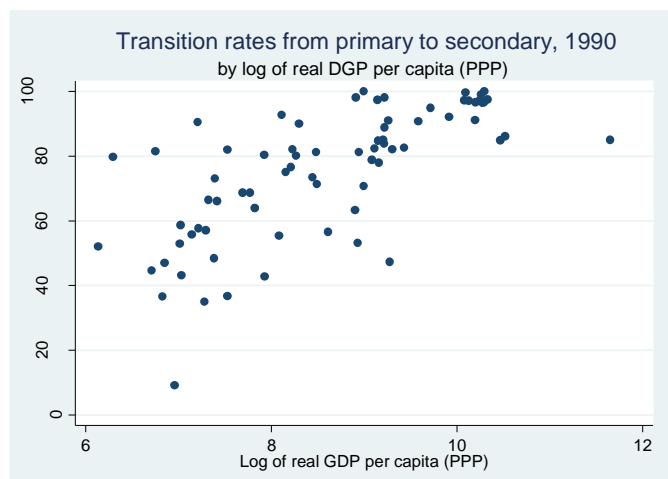

B: 2012

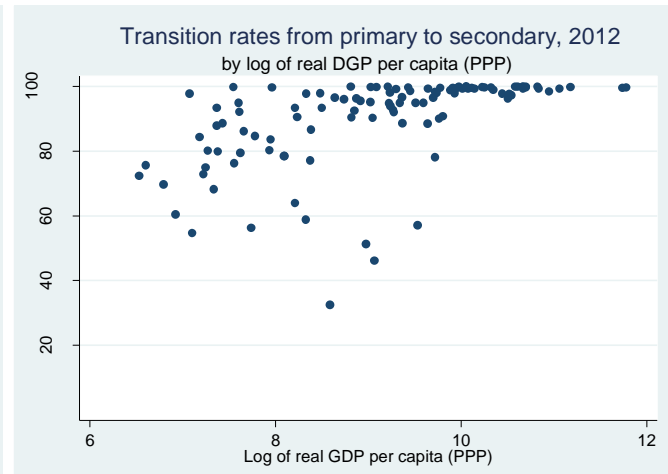

C: 1990 and 2012 trend lines

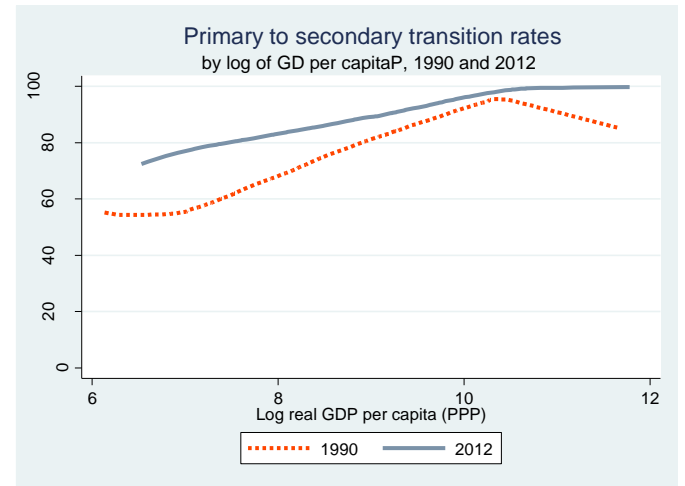

Notes: The larger number of data points in 2012 than in 1990 is because more countries now supply that information. Note that there was an outlier country in 1990 that dragged down the curve at the upper end.

Source: Data from World Data Bank and UNESCO Institute of Statistics (UIS)

This pattern of rising demand for education (in this case proxied simply by the transition rates from primary to secondary school) not only with rising level of development (level of per capita income) but also with time, offers some insight into the processes that determine the demand. On the one hand, the demand is tied to economic development. As the economy becomes more sophisticated, more people are drawn into the modern sectors where productivity and wages are closely related to education. The growth of high productivity sectors such as manufacturing and services draws people away from subsistence agriculture. As subsistence agriculture's share in the economy declines, jobs in the modern economy become more attractive and parents and children start seeing greater value in education. Urbanization as a result of rural-urban migration further contributes to this. On the other hand, the demand for education is also affected simply by time. Greater exposure to a modern world - through television, the media, the internet, mobile phones, and urban lifestyles - makes people value education more, as a means to becoming integrated into the modern world and economy.

\section{Education in the SACU countries: A brief background}

The five SACU (South African Customs Union) countries (Botswana, Lesotho, Namibia, South Africa, and Swaziland) have a common education system. The school year coincides with the calendar year. Primary education lasts seven years, usually starting at age 6 (for some countries, in the year the child turns 6 , in others the child must turn 6 before the middle of the year) and extending to age 12 . Secondary school lasts five years, from ages 13 to 17 . Tertiary education varies in duration; in South Africa degree programs typically last three years, but in the other 
four countries more often four years. The extent of compulsory education differs across the countries but includes all of primary education. However, as compulsory education is insufficiently enforced it has limited effect. Technical and vocational education and training (TVET), as yet not widely available, can be either decoupled from the school system or taken as a stream parallel to general upper secondary education. Three of the SACU countries, Botswana, Lesotho, and Swaziland, have examinations at the end of primary school that determine progression to secondary school. These three countries and Namibia also have examinations in Grade 10 that determine progression to the last two grades. Private education is uncommon, constituting about $4 \%$ of schools overall, but is somewhat more common in Botswana and much less so in Lesotho.

Table 1 provides estimates of enrolment numbers in various levels of education, taken from the UIS dataset for the most recent year available. The table shows the distribution of education across the countries, the education levels, and the school-age population aged 6 to 17 years. As South Africa is much larger than the other SACU countries (it constitutes well over $80 \%$ of the overall enrolment), its weight in some of the projections has a strong influence on the SACU aggregates. The years to which the data apply (the dataset has many missing values) means that the aggregate is only an approximation that does not apply to a given year. Broadly, it seems there were approximately 8.4 million children in primary education, 2.6 million in lower secondary education, and 3.2 million in upper secondary education, for a total of 14.2 million at school in the SACU countries around 2012. In addition, some 1.1 million students were enrolled in various tertiary education programs.

Table 1: Enrolment by education level, around 2012

\begin{tabular}{|l|c|c|c|c|c|c|}
\hline & Botswana & Lesotho & Namibia & South Africa & $\begin{array}{c}\text { Swazi- } \\
\text { land }\end{array}$ & Total \\
\hline Primary & 335,830 & 369,469 & $415,454^{\mathrm{d}}$ & $7,063,849^{\mathrm{d}}$ & 239,422 & $8,424,024$ \\
\hline Lower secondary & 120,546 & 95,454 & $124,448^{\mathrm{a}}$ & $2,190,820^{\mathrm{d}}$ & 61,871 & $2,593,139$ \\
\hline $\begin{array}{l}\text { Upper secondary } \\
\text { general }\end{array}$ & 52,123 & $35,104^{\mathrm{d}}$ & $39,756^{\mathrm{d}}$ & $2,651,157^{\mathrm{d}}$ & $28,933^{\mathrm{c}}$ & $2,807,073$ \\
\hline $\begin{array}{l}\text { Upper secondary } \\
\text { vocational }\end{array}$ & $8,873^{\mathrm{b}}$ & 4,488 &.. & $359,191^{\mathrm{d}}$ &.. & \\
\hline Upper secondary (all) & 60,846 & 39,089 & $33,714^{\mathrm{a}}$ & $3,010,348^{\mathrm{d}}$ & 28,943 & $3,172,940$ \\
\hline $\begin{array}{l}\text { Secondary (upper } \\
\text { and lower) }\end{array}$ & $181,741^{\mathrm{b}}$ & 134,543 & $158,162^{\mathrm{a}}$ & $5,201,168^{\mathrm{d}}$ & 90,814 & $5,766,428$ \\
\hline Tertiary & $55,128^{\mathrm{d}}$ & $24,073^{\mathrm{d}}$ & $19,707^{\mathrm{b}}$ & $1,005,721$ & $8,057^{\mathrm{d}}$ & $1,112,686$ \\
\hline $\begin{array}{l}\text { School-age } \\
\text { population 6-17 } \\
\text { ('000s) }\end{array}$ & 529 & 601 & 644 & 12,445 & 12,445 & 361 \\
\hline
\end{tabular}

Note: $a-2007$ data, b-2008 data, c-2011 data, d-2013 data

Source: UNESCO Institute of Statistics 2014

Early Childhood Development (ECD) is at various stages of development in the SACU countries, and not yet well established in any of them. The value of ECD has been well recognized in the literature, including the economics literature, where the work of Nobel laureate James Heckman has been particularly influential. He and his co-authors have shown that returns on investment are greatest for the young because they can generate a return over a longer time horizon and because "skill begets skill." Heckman and Masterov (2007) argue that investing in disadvantaged young children reduces inequality and raises the productivity of society as a whole. Returns to later investment and remediation for disadvantaged young adolescents are low, while early investments have high returns (Heckman, 2007). 
The Namibian National Development Plan acknowledges the importance of ECD and the need for increased investment in it:

The challenges relating to the quality of education start with the limited access to early childhood development (ECD) services. ECD refers to the growth and change that take place from preconception until the age of 6 . In these early years, the most critical neurological development takes place, with the most significant brain growth occurring in the first three years of life.... ECD is generally under-valued and often misunderstood. Moreover, investment in ECD is low - although the potential returns of quality ECD have been shown to be very high. (Namibia, National Planning Commission, 2012: 46-7)

The need for early intervention is evident in the SACU countries, where very few children grow up in a print-rich environment in which access to books would enable them to develop a culture of reading. Table 2 shows that between 22\% and 34\% of children in Grade 6 in these countries had no books in their home; in Lesotho, where access to books is lowest, only $8 \%$ of children had more than 20 books in the home, and in Botswana, with the highest access, this proportion still only reaches $20 \%$.

Table 2: Number of books in the home (percentage of children in Grade 6), 2007

\begin{tabular}{|l|c|c|c|c|c|}
\hline & Botswana & Lesotho & Namibia & South Africa & Swaziland \\
\hline No books & 22 & 34 & 27 & 30 & 32 \\
\hline $1-10$ books & 46 & 49 & 48 & 41 & 44 \\
\hline $11-20$ books & 13 & 8 & 11 & 11 & 10 \\
\hline More than 20 books & 20 & 8 & 14 & 17 & 13 \\
\hline
\end{tabular}

Source: Authors' calculation from SACMEQ III

UNICEF (2015) notes that "it is difficult to report on ECD access largely due to the age range of children involved, and the varied approaches used," but says that available data suggest very low coverage across eastern and southern Africa, though the situation is improving. In some of the SACU countries, ECD initiatives include adding an extra year before Grade 1 (variously called pre-primary education, Grade $\mathrm{O}$, reception year, or Grade R) to the schools system and attempting to make this compulsory once there are enough places available. In South Africa, a second pre-grade- 1 year is now also envisaged. In addition, some attempts are being made to reach children at an even earlier age through community-based ECD facilities, but the coverage and the quality still leave much to be desired and much further investment and institutional development will be required before these facilities will make a substantial contribution.

\section{Data on which the projections are based}

The future demand for education is likely to be affected by a number of factors, such as the size of the school-going age group, the demand from individuals and households, a country's level of development, and the effects of the passage of time.

The size of the school-going age group is of crucial importance, thus the total demand for education is closely related to the demographic projections. The projections by the United Nations Population Division (2015 revision) are used in this paper. Of particular concern is the age group 6 to 17 years. $^{5}$

\footnotetext{
${ }^{5}$ As mentioned, SACU countries have slightly different school entry ages. Some of the UN data refer to the second half of the school year, when children are older. Thus a case can also be made for using ages 7 to 18 as the school-age population. However, this difference has little effect on the broad patterns and trends discussed in this paper.
} 
The demand for education from individuals and households will determine what proportion of children of school-going age will actually be at school (assuming that schools are available). Applying this proportion for each age group to the demographic projections makes it possible to estimate the total demand for education for the two target years for this study, 2030 and 2050.

The demand is of course also influenced by the development level of a country and the time period. Actual patterns of progress in individual countries reflect the joint effects of development and time on the demand for education. This joint effect can be shown for each of the countries under review.

The data for this study are obtained from censuses and surveys. This obviates the need to depend unduly on EMIS (education management information system) data, which vary in quality across the countries concerned and are often inflated, since incentives can lead schools and teachers to exaggerate enrolment. Census and survey data make it possible to investigate longterm trends in educational attainment. For Botswana, Namibia, and South Africa the 2011 censuses are used, and for Lesotho and Swaziland the 2010 labor force surveys.

To check the quality of the data, the patterns of educational attainment by year of birth observed in the labor force surveys were compared to those obtained from demographic and health surveys. The patterns were found to be remarkably similar, giving greater confidence in the accuracy of the data. Because the numbers in each age group in the survey data are much smaller than those in the census data, the measurement error will be greater in the survey data. Some smoothing of time trends was therefore done by using three-year moving averages in the graphs for Lesotho and Swaziland. Naturally, the older cohorts' educational attainment will be slightly over-estimated due to selective survival, as poorer and less educated people have higher mortality rates. If all had survived, the slope of the curves would have been even steeper.

Looking at the graph for Botswana (Figure 2A), two immediate observations may be made. The first is how small the vertical distance is between the curves for Grade 1, Grade 5, and Grade 7. This indicates that most of those who started primary school completed it, and it can be seen that this has become more common over the years. The second is the very rapid rise in the proportion of the cohorts born in the latter half of the 1970s who reached Grade 10, with the result that the gap between the curves for Grade 10 and Grade 7 is now fairly small, reflecting high continuation rates to secondary school. The gap between these grades and Grade 12 is still fairly large, though.

Figure 2B shows that many of those born in Lesotho in 1990 (the most recent birth year shown in the graph) would have completed most of their education at the time of the survey (2010), but some might still have been enrolled in higher levels of education, so the data for Grade 12 include only those turning at least 22 in the year of the survey (2010) and for tertiary education only those 26 years or older, i.e. born in 1984 or earlier. From these data it is possible to see what progress has been made in getting children to attend school: well over $90 \%$ of the youngest cohorts had completed at least Grade 1, as compared to barely a quarter of those born in 1930. Compared to the other SACU countries, a larger proportion of Lesotho's population at least started education in the early years shown in Figure 2B. For example, more of those born around 1930 and in the next two or three decades had completed at least Grade 1. However, it is clear that the gap between those who had completed at least Grade 1 and those with at least Grade 5 was initially very large, indicating massive dropout before Grade 5. This dropout rate has decreased, as can be seen from the narrowing of the gap between the curves for these two grades.

Another notable feature of this graph is that the curve flattens for Grade 1 around the 1950 birth cohort, with little progress since; for Grade 5, the flattening comes later, around the 1970 
birth cohort. Since then, little progress has been made in attracting more children to school or getting them to stay there at least until they complete Grade 5. A similar trend is evident for the completion of primary school (Grade 7): here too the rate seems to stagnate somewhat after the early 1970 s.

Figure $2 \mathrm{C}$ shows that Grade 1 completion is still worrying low in Namibia, indicating that a substantial proportion of children never attend school. The gaps between Grade 1 and Grades 5 and 7 have narrowed, indicating increasing progression through primary school. Grade 10 and Grade 12 completion levels are still much lower. The downward slope of the Grade 10 curve in recent years is perhaps in part the result of grade repetition, which means that some children complete Grade 10 at ages that are higher than the norm for this grade.

South Africa's high completion rates for primary school, as shown in Figure 2D, are encouraging, as is the narrowness of the gap between these curves and the curve for Grade 10. Even the Grade 12 curve ("matric" in South African terminology) shows fairly high levels of completion of secondary school, though that trend seems to be flattening off. The slight decreases in completion rates in 1930, 1940, and 1950 are artificial: they are the result of a phenomenon well known to demographers and historians, namely age rounding, where persons who are illiterate tend to provide either an age that is rounded or, in this case, birth years that are rounded.

In Swaziland, as Figure 2E shows, the gaps between those completing Grade 1 and the higher primary grades are relatively large, reflecting high dropout during the primary phase. The leveling off of the Grade 10 and Grade 12 curves may also reflect the fact that some of those eventually completing these grades may do so at ages that are higher than the norm.

Data drawn from censuses and labor force surveys such as those shown in Figure 2 provide the basic source of information for the demand projections in Sections 3 and 4 of this paper. The patterns and levels observed in the surveys on which these graphs are based offer a historical perspective that is not widely or consistently available from other data sources. Moreover, EMIS data are not as comparable for the SACU countries, and differ in their reliability. 
Figure 2: Percentage of each birth cohort that had completed at least the education levels indicated

\section{A: Botswana}

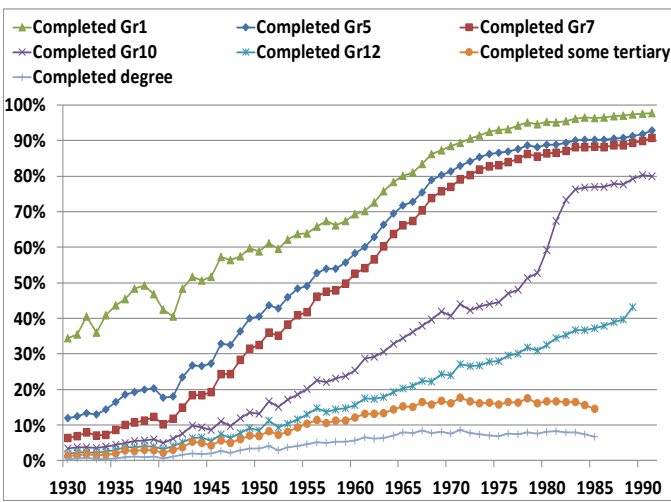

C: Namibia

\section{B: Lesotho}

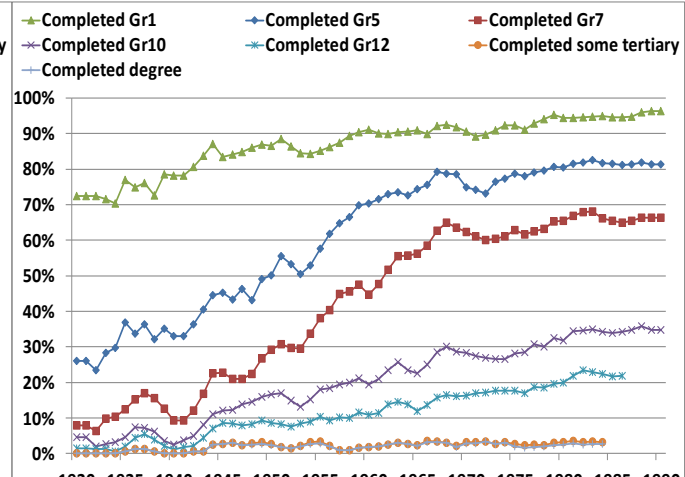

1930193519401945195019551960196519701975198019851990

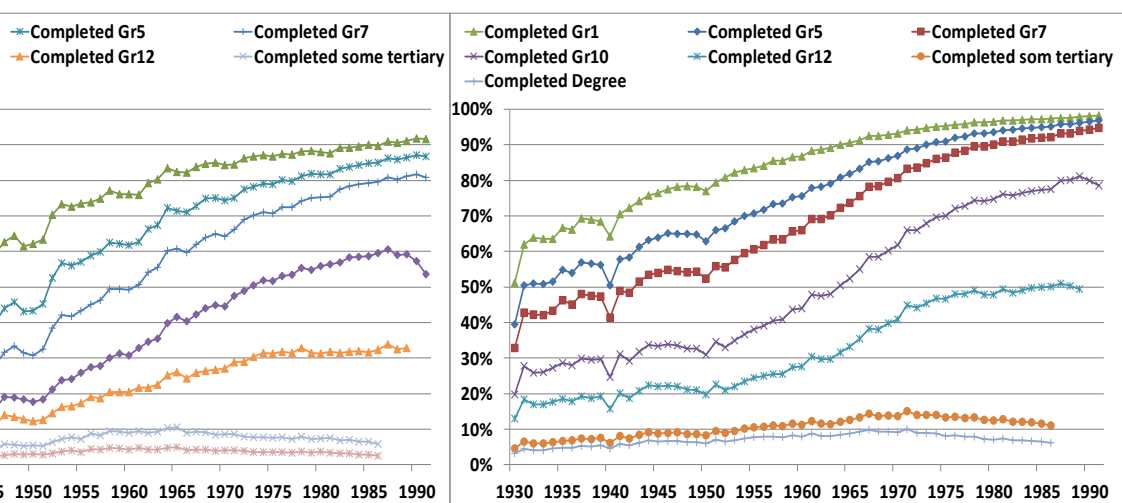

\section{E: Swaziland}

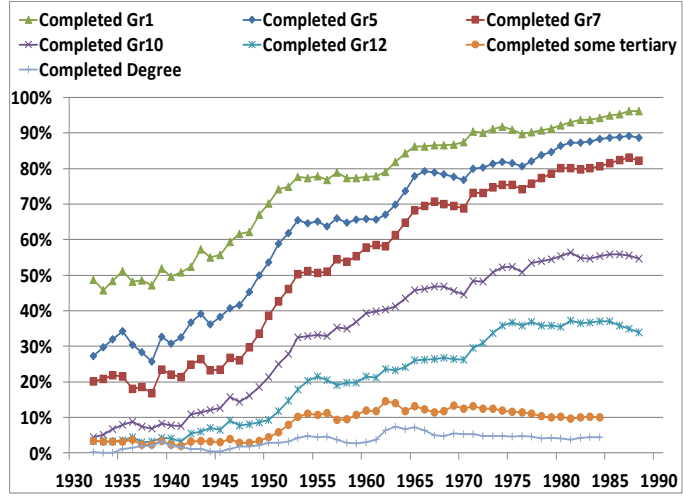

Source: 2011 censuses (Botswana, Namibia, South Africa); 2010 labor force surveys (Lesotho, Swaziland)

Whereas Figure 2 showed the completion levels for selected grades, the five graphs in Figure 3 depict the broad patterns of attainment of various birth cohorts. The white part of the graphs represents the proportion of the cohort that went on to complete Grade 12 or even beyond. As is apparent, this proportion has been increasing for all five countries. (The slight decrease in recent years is artificial: it simply means that some younger cohorts have not yet completed their education.) The remarkable progress made in Botswana is also clear compared with the position six decades earlier. 
Figure 3: School attainment by birth cohort
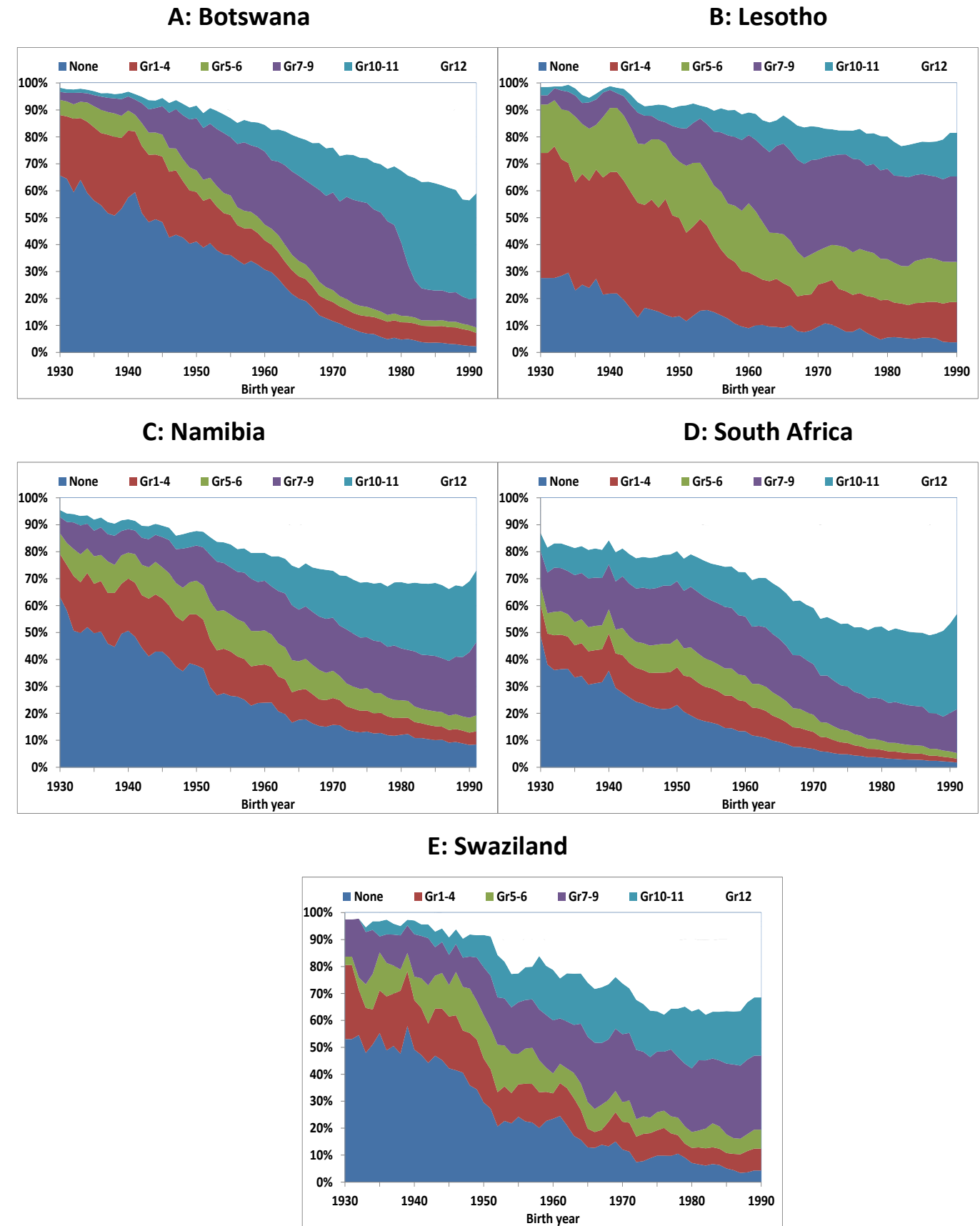

Source: 2011 censuses (Botswana, Namibia, South Africa); 2010 labor force surveys (Lesotho, Swaziland

Figure 4 shows the proportion of each birth cohort that never entered school, a proportion that has decreased strongly but is still worryingly high in Namibia, at around $8 \%$ in the most recent birth cohort. 
Figure 4: Percentage of birth cohort that have never attended school

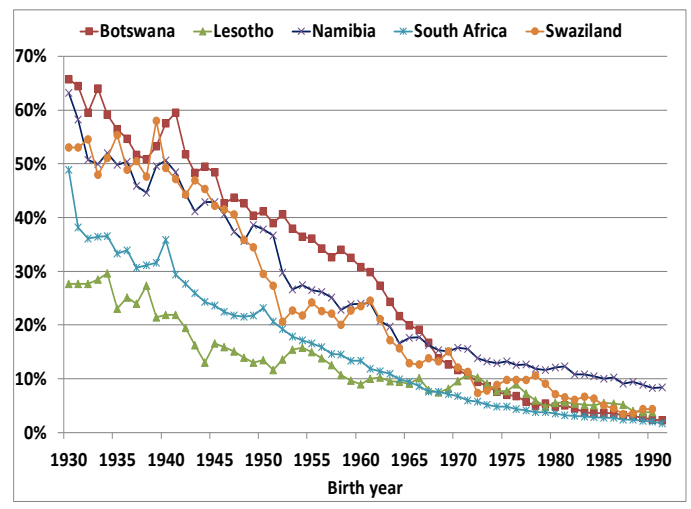

Figure 5 shows completion rates for Grades 5, 710 , and 12 across the five countries. Completion of Grade 5 has increased considerably in the past six decades, with South Africa still maintaining a slight lead and Lesotho not doing very well. In Grade 7 in particular Lesotho's progress has fallen behind that of the other SACU countries in recent years. The most prominent feature of Figure $5 \mathrm{C}$ is the rapid progress that was made in Botswana's Grade 10 completion rates by the cohorts born in the late 1970s and early 1980s. Progress in the country's Grade 12 completion rates has been less rapid. Lesotho's backlog is growing due to very slow progress in the proportion of cohorts that complete Grade 10.

Figure 5: Percentage of birth cohort that completed various grades:

\section{A: Grade 5}

B: Grade 7
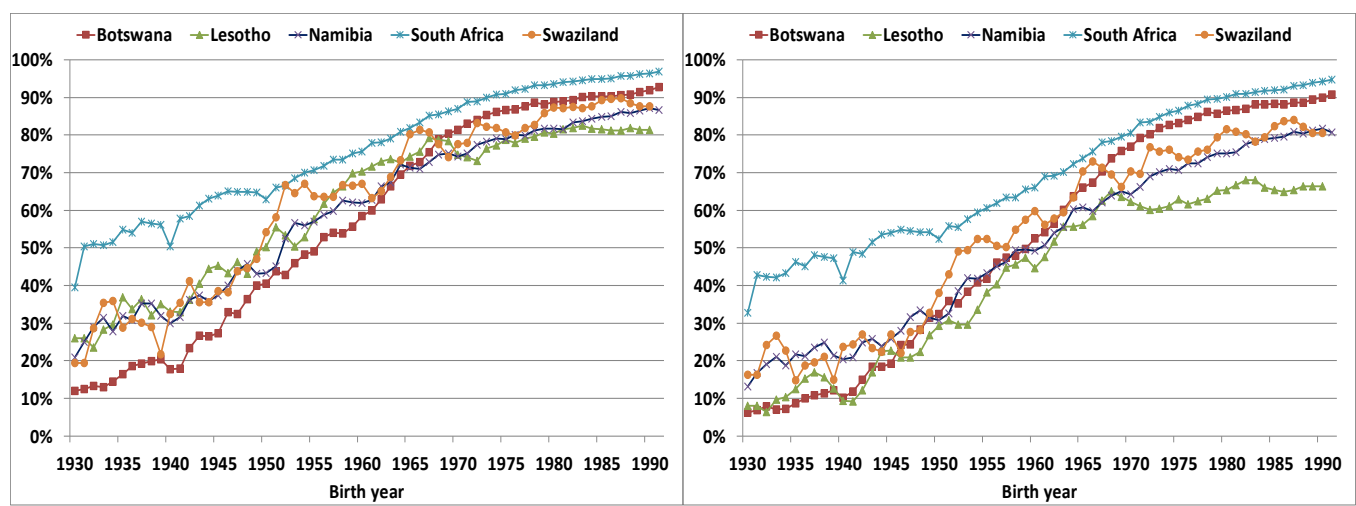

C: Grade 10

D: Grade 12

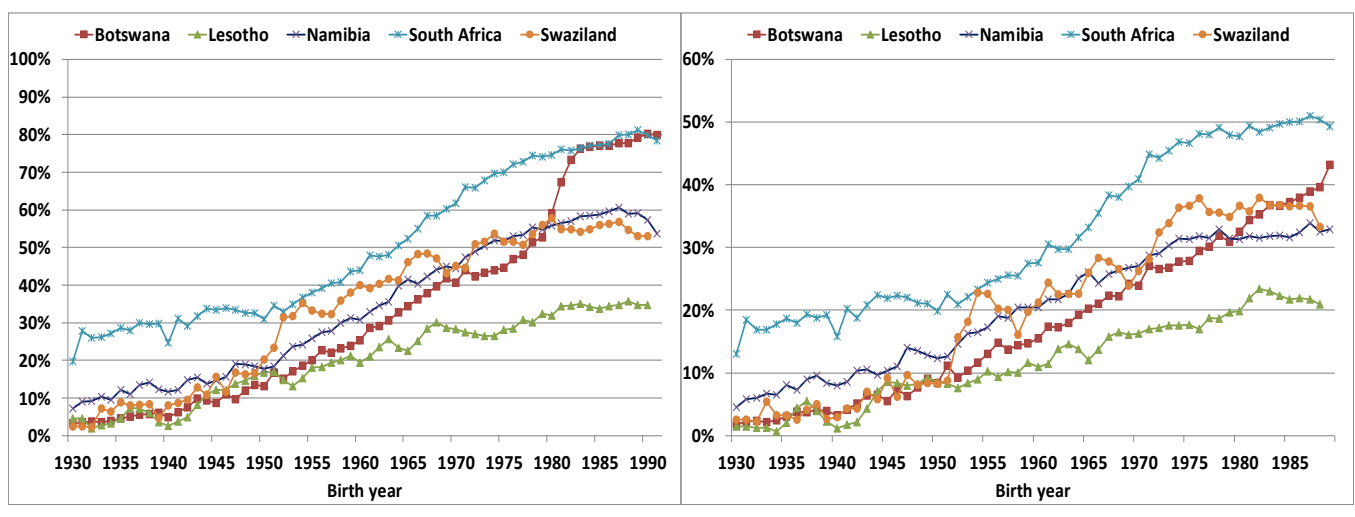

Source: 2011 censuses (Botswana, Namibia, South Africa); 2010 labor force surveys (Lesotho, Swaziland

The discussion of Figures 2 and 3 above was confined to completion of primary and secondary 
education. For tertiary education, for at least three reasons, there are no clear trends. Firstly, the smaller numbers completing various forms of tertiary education imply that measurement error, particularly in the surveys but even in the censuses, plays a bigger role and makes trends less observable. Secondly, the diverse nature of tertiary education affects patterns and trends both within and across countries. For instance, the survey and census data do not always make it possible to distinguish between forms of tertiary education that require at least Grade 12 for admission and forms that have lower admission requirements, meaning that the latter should not really be regarded as tertiary. In Botswana, just under half of tertiary students are at universities (Bailey, Cloete, and Pillay, 2011). Thirdly, in some instances institutional factors affect the age at which many people obtain tertiary education. In Namibia, for instance, many of those obtaining tertiary qualifications do so only when already well into their thirties or forties, as there are strong incentives for teachers to improve their qualifications through distance learning.

These three factors make tertiary patterns and trends difficult to interpret. Moreover, and perhaps most importantly, demand for education and actual access to education diverge more at the tertiary level. For school-aged children in the SACU countries, latent demand for education is relatively easily translated into actual demand, as there is no serious shortage of places at schools and restrictions on child labor limit the opportunity cost of studying. In contrast, the numbers in tertiary education reflect not so much the demand for education as the supply of places in tertiary education institutions and the availability of funding, such as bursaries and scholarships, that enables students to study rather than get a job. Latent demand is thus much bigger than the observed demand.

Figure 6A shows tertiary enrolment rates in the SACU countries for the population aged 18 to 22 years. Although these show strong growth, they are still far below those of the OECD countries as shown in Figure 6B.

Figure 6: Tertiary enrolment in SACU countries, and in SACU countries compared with OECD countries

A: SACU countries only

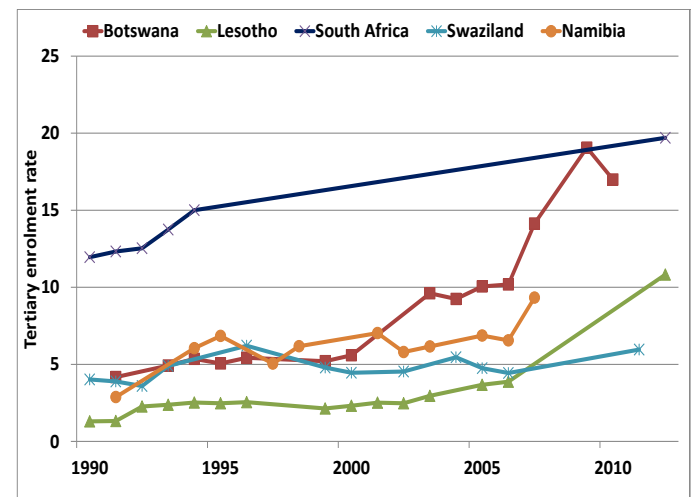

B: SACU countries and OECD

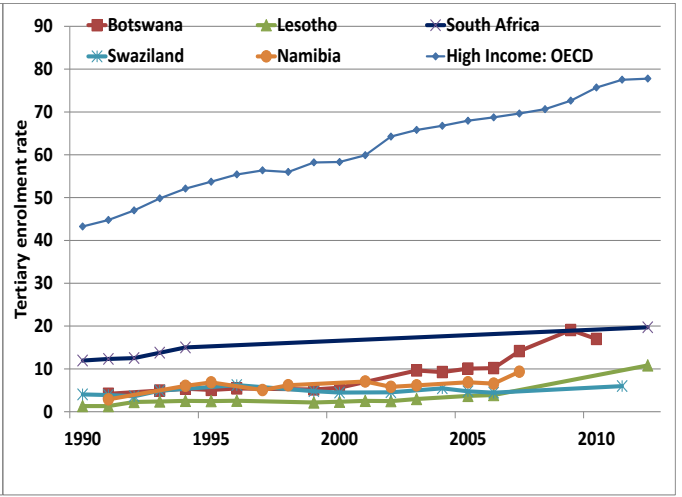

In Namibia in 2010, because of space and financial constraints the two public universities could admit only about one-third of the students who qualified and applied. The applications were from almost two-thirds of the students who had completed secondary school the previous year. As a result, many Namibian students continue to cross the borders into South Africa and elsewhere to gain access to higher education. In Botswana too, only a small proportion of school leavers make the transition to higher education. The situation has been exacerbated by the decline in funding for students and the increasing demand for higher education. Public funding has supported many of the thousands of students from Botswana who are studying at South African and overseas universities, but recently the situation has deteriorated due to the decline in funding and the increasing demand for higher education (Siphambe and Motswapong, 2011). 
In South Africa, scarcely one-fifth of the students applying to eleven universities (including the distance university UNISA) were admitted. ${ }^{6}$

UIS data, which are available only for some years for some countries, show that 6,549 students graduated from tertiary institutions in Botswana in 2013, 4,747 in Lesotho in 2010, 5,525 in Namibia in 2008, 183,864 in South Africa in 2012, and 2,525 in Swaziland in 2012. These figures are not very reliable, however, and for those countries for which data are available for several years, the numbers fluctuate greatly.

Table 3 and Figure 7 show the proportion of the population aged 6 to 24 attending school by age in each of the SACU countries, based on the census and survey data. Participation rates are high in the younger age groups but more varied in the older groups. Participation is close to universal at the primary level. Differences in school starting ages in the SACU countries, as explained earlier, and the timing of the censuses and surveys relative to the school year (some were early in the school year, most later) exacerbate some differences in participation rates. Further, the censuses and surveys do not always make it clear what "attending school" means. Respondents whose children were in pre-school, for example, or respondents who had left school for technical and vocational education and training (TVET), may not have known how to answer this question.

The data show that the participation rate peaked well above $90 \%$ for four of the five countries, with the exception of Namibia, which nevertheless had a rate of over $90 \%$ from ages 7 to 14 . Lesotho shows a considerable drop in participation rates from age 14, whereas for Botswana, South Africa, and Swaziland the rate drops only from age 16. Due to high repetition, many persons as old as 24 are still in school, though it is not always possible to tell what proportion of those who said they were 'in school' meant precisely this.

Table 3: School (or other educational institution) participation rates by age for SACU countries, 2011 (and 2010 for Swaziland)

\begin{tabular}{|l|r|r|r|r|r|r|}
\hline Age & $\begin{array}{c}\text { Botswana } \\
\mathbf{2 0 1 1}\end{array}$ & $\begin{array}{c}\text { Lesotho } \\
\mathbf{2 0 1 0}\end{array}$ & \multicolumn{1}{|c|}{$\begin{array}{c}\text { Namibia } \\
\mathbf{2 0 1 1}\end{array}$} & $\begin{array}{c}\text { South } \\
\text { Africa } \\
\mathbf{2 0 1 1}\end{array}$ & $\begin{array}{c}\text { SA: } \\
\text { school } \\
\text { only } \\
\mathbf{2 0 1 1 ^ { a }}\end{array}$ & $\begin{array}{c}\text { Swaziland } \\
\mathbf{2 0 1 0}\end{array}$ \\
\hline 6 & 62.9 & 79.9 & 35.2 & 92.6 & 89.0 & 83.6 \\
\hline 7 & 91.2 & 92.1 & 77.3 & 96.2 & 95.4 & 94.7 \\
\hline 8 & 94.4 & 91.4 & 88.9 & 96.7 & 96.4 & 97.5 \\
\hline 9 & 95.5 & 93.7 & 91.2 & 97.0 & 96.7 & 94.5 \\
\hline 10 & 95.5 & 94.5 & 90.0 & 96.7 & 96.3 & 96.5 \\
\hline 11 & 95.7 & 94.1 & 88.7 & 96.8 & 96.4 & 97.4 \\
\hline 12 & 97.3 & 93.3 & 88.6 & 96.1 & 95.7 & 96.6 \\
\hline 13 & 96.9 & 92.6 & 86.8 & 96.0 & 95.5 & 95.2 \\
\hline 14 & 96.1 & 91.0 & 85.1 & 95.4 & 94.9 & 92.3 \\
\hline 15 & 93.7 & 80.6 & 81.8 & 93.9 & 93.4 & 91.6 \\
\hline 16 & 89.0 & 72.9 & 78.6 & 90.7 & 89.9 & 87.8 \\
\hline 17 & 78.4 & 64.4 & 72.3 & 85.5 & 84.3 & 79.1 \\
\hline 18 & 602 & 54.0 & 61.0 & 74.2 & 68.8 & 67.6 \\
\hline 19 & 40.3 & 46.8 & 47.8 & 58.6 & 46.6 & 49.6 \\
\hline 20 & 30.7 & 39.0 & 34.9 & 45.5 & 30.3 & 35.4 \\
\hline
\end{tabular}

\footnotetext{
${ }^{6}$ The admittance rate is in fact somewhat higher than the statistics suggest, as many applicants had applied at more than one university.
} 


\begin{tabular}{|c|c|c|c|c|c|c|}
\hline 21 & 24.5 & 30.4 & 26.7 & 35.0 & 20.2 & 28.0 \\
\hline 22 & 18.9 & 23.1 & 20.2 & 25.1 & 12.4 & 21.3 \\
\hline 23 & 12.8 & 15.9 & 12.3 & 19.0 & 8.6 & 8.9 \\
\hline 24 & 9.9 & 14.2 & 9.3 & 14.8 & 6.3 & 11.1 \\
\hline $\begin{array}{l}\text { School-age population } \\
6-17\end{array}$ & 529 & 601 & 644 & 12,445 & 12,445 & 361 \\
\hline $\begin{array}{l}\text { School-age population } \\
\text { attending school }\end{array}$ & 478 & 522 & 517 & 11,755 & 11,655 & 333 \\
\hline $\begin{array}{l}\text { Full population } \\
\text { attending school }\end{array}$ & 565 & 627 & 619 & 14,621 & 13,680 & 399 \\
\hline Net enrolment rate & $91 \%$ & $87 \%$ & $80 \%$ & $94 \%$ & $94 \%$ & $92 \%$ \\
\hline Gross enrolment rate & $107 \%$ & $104 \%$ & $96 \%$ & $117 \%$ & $110 \%$ & $110 \%$ \\
\hline $\begin{array}{l}\text { Enrolment based on } \\
\text { grade completion }{ }^{b}\end{array}$ & 458 & 502 & 428 & 10,184 & 10,184 & 282 \\
\hline $\begin{array}{l}\text { Implied under- } \\
\text { estimation }{ }^{c}\end{array}$ & $23 \%$ & $25 \%$ & $45 \%$ & $33 \%$ & $25 \%$ & $41 \%$ \\
\hline
\end{tabular}

Source: Own calculations based on estimated completion rates of various grades from survey and census data applied to the UN Population Division population estimates (2015 revision).

Notes: a Rates when definition of "school" was clarified. b For more on these completion rates, see the discussion below on projecting the demand for education. ${ }^{c}$ Assuming school attendance data are correct, i.e. calculated as the proportion by which the full population attending schools exceeds the enrolment implied by grade completion rates.

Figure 7: School (or other educational institution) participation rates by age for SACU countries, 2011 (and 2010 for Swaziland)

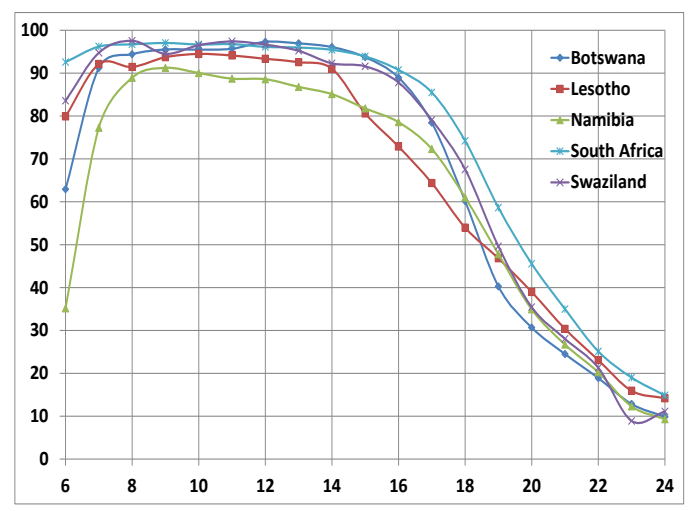

Source: Derived from survey and census data

It must be noted that definitional problems at the higher age groups affect these rates to some extent. Data from the South African census provide some insight into this problem. This census asked whether persons attended "an educational institution", whereas in Namibia and Botswana the question was simply whether they attended "school". This is open to interpretation, as exemplified by the fact that many respondents in Namibia well into their $20 \mathrm{~s}$ and beyond said they were attending school, including some who had already completed Grade 12; apparently the term "school" is sometimes more widely interpreted than in the more common southern African usage. In South Africa, those who said they were attending an "educational institution" were also asked what type of institution they attended. Figure 8 shows for South Africa the attendance at all educational institutions, compared to attendance only at schools. The two curves largely coincide, except for slight differences at age 6 , where there could be confusion between school and early childhood education institutions, and larger differences from age 17, where some respondents who said they were at school were in fact at TVET institutions or other colleges and universities. 
Figure 8: Participation rates by age in South Africa in all educational institutions and in schools, 2011

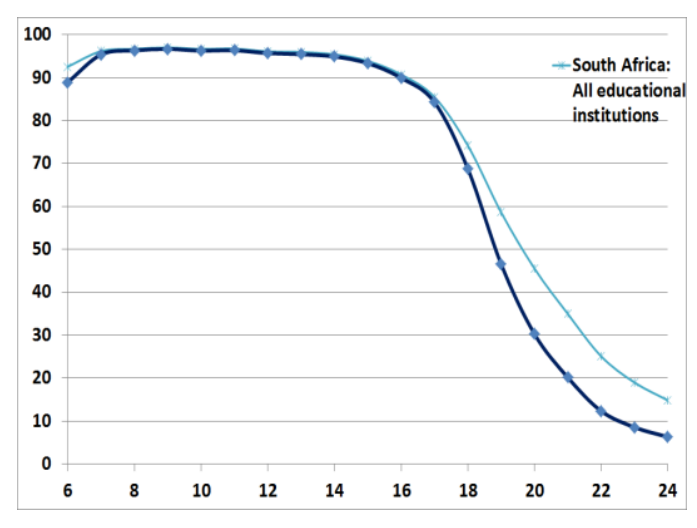

The data presented in Table 3 imply a gross enrolment rate ranging between Namibia's $96 \%$ and South Africa's $117 \%$, but the latter drops to $110 \%$ when those attending other educational institutions are excluded. It is possible that some of these rates for other countries are upwardly biased in the same way as South Africa's because of definitional problems.

To be less dependent on survey and census definitions of school attendance, it is useful to again turn to the completion (attainment) rates by age, which will be discussed in more detail below. Applying the estimated grade completion rates for each birth cohort, as derived, to the population numbers by age group yields the enrolment numbers in the absence of repition (the second last row in Table 3 ). The extent to which the calculated enrolment exceeds the enrolment as derived from grade completion numbers (assuming no repetition) indicates the extent of the inflation of attendance numbers due to the combination of definitional problems and the effect of grade repetition on the number of years spent in school. ${ }^{7}$ The difference ranges from $23 \%$ to $45 \%$, as the last row of Table 3 shows.

\section{Projecting of completion rates for the SACU countries}

\section{Primary school projections}

Figure 9A shows the international cross-country primary completion rates by the log of real 2011 GDP per capita, in PPP terms, for two years, 1990 and 2013. The lines are based on cross-country data for all countries for which data were provided in the World Data Bank. Of the SACU countries this includes only Lesotho. The vertical lines have been added to show the natural log of per capita GDP of the five SACU countries in 2013, to indicate where these countries could be expected to be located: Lesotho (7.81), Swaziland (8.70), Namibia (9.14) South Africa (9.43), and Botswana (9.69). Note that the international trend line of primary completion peaks at close to universal completion of primary education in 2013 for countries somewhere above the income level of Swaziland and below that of Namibia. Note also how the trend has shifted upward over time: it is not only the level of economic development that induces greater participation in education, but also time itself. Like the primary completion rate, net enrolment in primary education (Figure 9B) also shows an upward trend over time, but achieving $100 \%$ net enrolment is still further off, as some children at primary school are outside the ages set for

\footnotetext{
${ }^{7}$ The completion rate method implies that school enrolment in each grade will be such as to generate the observed completion rates, assuming no repetition.
} 
primary school, even in countries with developed economies: they either enter primary school late, or in rare cases exit it early to enter secondary school. ${ }^{8}$

Figure 9: Primary completion and net enrolment rates derived from international crosscountry trends, 1990 and 2013

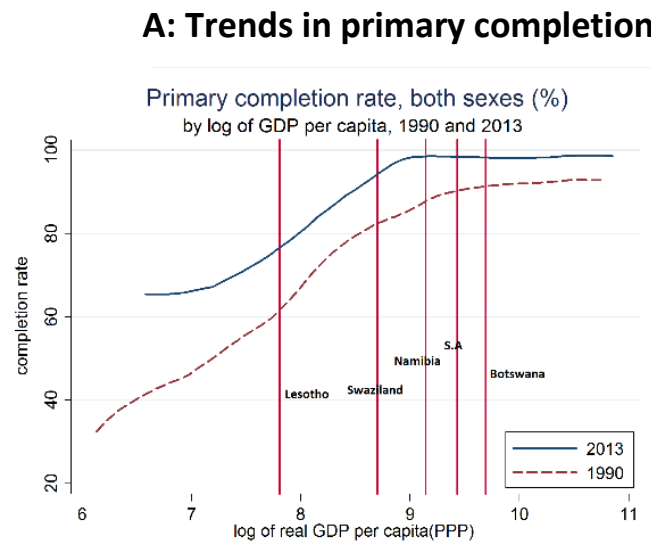

\section{B: Trends in net enrolment rates}

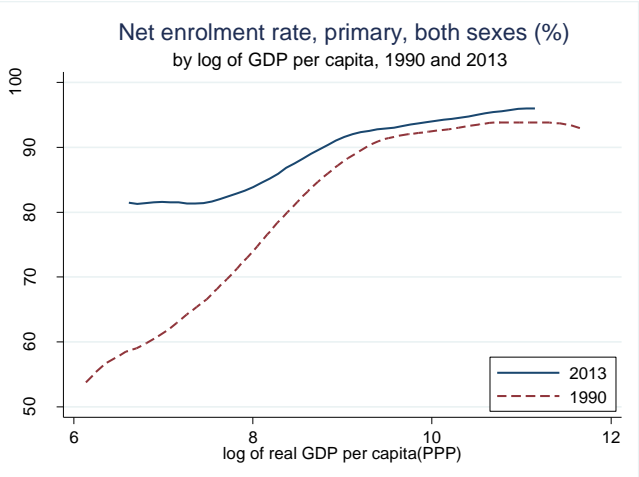

Source: Data from World Data Bank and UNESCO Institute of Statistics (UIS)

By 2013 all the SACU countries were approaching universal enrolment of the primary schoolaged population, i.e. universal net enrolment. The small differences in school entry age and the part of the school year when data on participation were collected affect this slightly, but only Namibia faces a real problem in attaining these higher levels. However, even Namibia could soon reach close to universal primary net enrolment.

In terms of the projections of access to schools (i.e. completing at least Grade 1), it appears that all five SACU countries' education systems are tending to universal access. The rate of progress towards universal enrolment is likely to slow as only the most marginalized communities remain outside the net. This has also been found in other countries that have passed through these stages. Therefore it is assumed that $5 \%$ of the difference between current enrolment levels and universal enrolment would be eliminated annually, i.e. that

$$
\mathrm{C}_{\mathrm{t}+1}=\mathrm{C}_{\mathrm{t}}+\left(1-\mathrm{C}_{\mathrm{t}}\right) / 20
$$

(Equation 1)

Thus, enrolment in Grade 1 is assumed to asymptotically approach universal enrolment; when the gap is large, the enrolment rate is likely to grow more rapidly than when there is only a small gap. This is shown in Figure 10A.

All five SACU countries are also approaching universal completion of primary schooling, as Figure 10B (for Grade 5) and Figure 10C (for Grade 7) show. Thus the same formula is used to project completion of these two grades. The actual and projected completion rates for these three primary grades are shown in Figures 10A, B, and C, and the projected rates for 2015, 2030, and 2050 are shown in Table 4.

\footnotetext{
${ }^{8} \mathrm{Net}$ enrolment is the enrolment of children of the primary age groups in primary school, as a proportion of all children in that age group.
} 
Figure 10: Completion rates, actual and projected, for various grades

A: Grade 1 completion rates

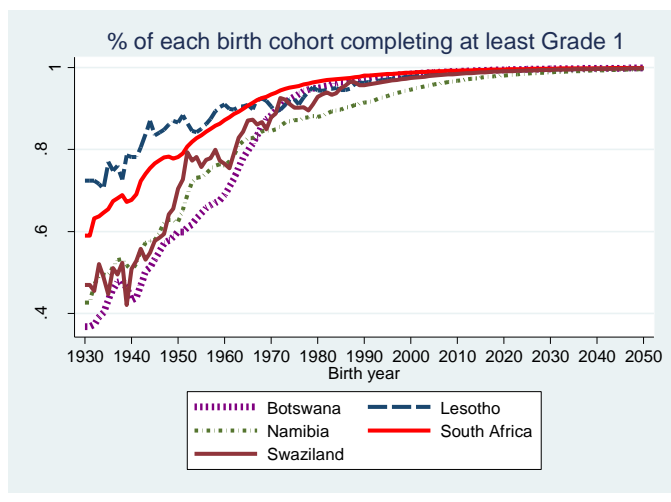

C: Grade 7 completion rates

\section{B: Grade 5 completion rates}

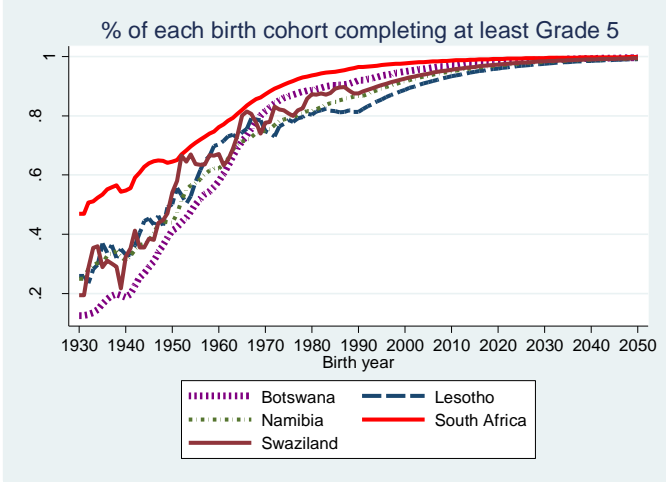

D: Grade 10 completion rates
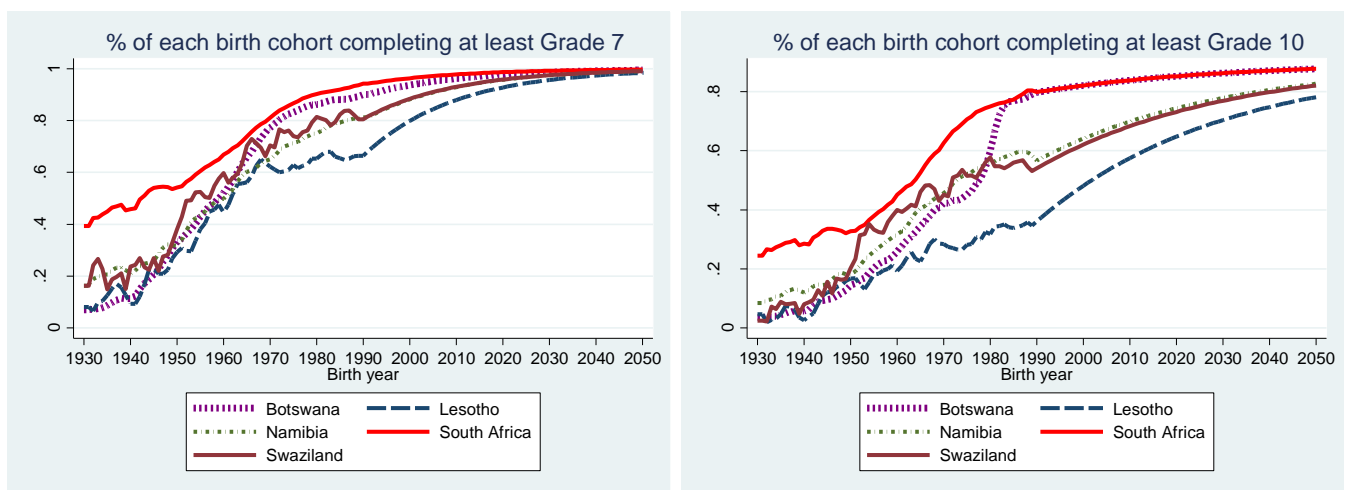

\section{E: Grade 12 completion rates}

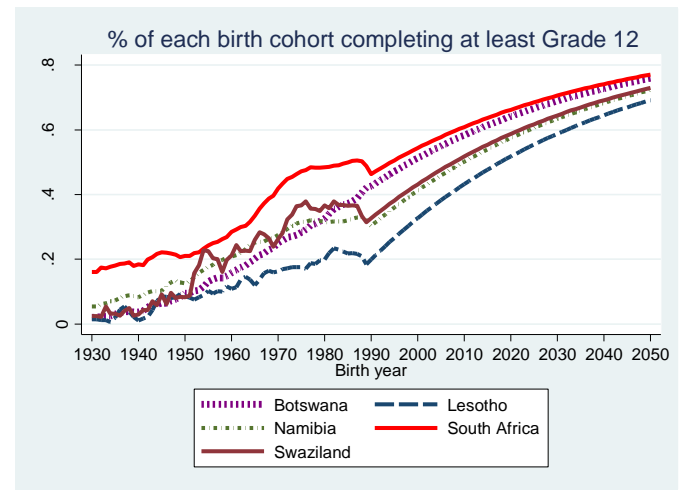

\section{Secondary school projections}

Enrolment in schools has risen worldwide, and the initial increases in primary school have now been followed by similar increases in secondary schools. Figures $11 \mathrm{~A}$ and $11 \mathrm{~B}$ show that the initial lower levels of gross enrolment for girls in poorer countries are now less common (girls currently have no enrolment backlog in SACU countries $^{9}$ ). Whereas there was initially a strong

\footnotetext{
${ }^{9}$ Examples to illustrate this can be found in the World Bank's Educational Attainment datasets that are based on household surveys and demographic and health surveys. These show that net enrolment for boys aged 6 to 14 was 82\% for boys and 89\% for girls in Lesotho in 2004, 86\% and 88\% in Namibia in 2006, and $90 \%$ and $91 \%$ in South Africa in 1999. Similarly, median attainment was a year higher for girls aged 15 to 19 than for boys in each of these three countries (for girls, these values were 7 years in Lesotho and 9 years in the other two countries).
} 
social gradient for both genders (gross enrolment rates rising strongly with higher levels of per capita GDP), this gradient is now much flatter and there is higher enrolment right across the development spectrum. In fact, gross enrolment in primary and secondary schools combined the population in school expressed as a proportion of the population of school-going age - is now well above $100 \%$ in some countries, largely reflecting grade repetition. So strong has the demand for education become in most countries of the world, and particularly in middle-income countries such as those in the SACU, that the average child now spends more than 12 years at school. Low internal efficiency (repetition) keeps gross enrolment rates above $100 \%$.

Figure 11: Trends in cross-country gross enrolment rates for girls and for boys for primary and secondary school combined, 1990 and 2013

\section{A: Gross enrolment rates for girls}

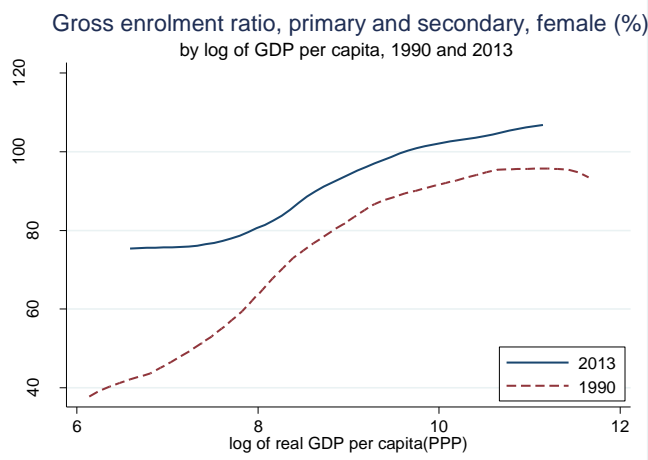

\section{B: Gross enrolment rates for boys}

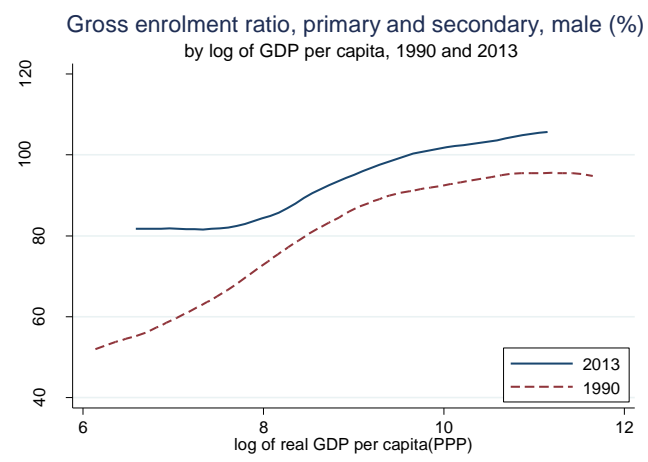

Source: Data from World Data Bank and UNESCO Institute of Statistics (UIS)

To put the position of the SACU countries in perspective, it is useful to consider that the log of current GDP per capita in PPP dollars ranges from Lesotho's 7.81 to Botswana's 9.69. Moderate economic growth of about $2 \%$ per annum until 2030 would increase these numbers by about 0.34, and similar growth to 2050 by about 0.73 . Gross enrolment rates close to or even exceeding 100 are therefore to be expected in the SACU countries for the two projected periods, particularly considering that the international cross-country trend for a rising but flattening curve is likely to continue.

The growing trend to stay in school longer is also reflected in Namibian data for various age groups derived from the census (Figure 12). The proportion of the age group 20-24 that has reached at least Grade 10 is now 59\%, whereas for those now aged over 80 this proportion was less than $10 \%$. Yet despite this progress, the graph still shows a decline at higher education levels, both because some children drop out early and because many of them repeat. By Grade 7, 35\% of Namibian students are at least two years too old for their grade, despite restrictions placed on repetition. 
Figure 12: Percentage of selected age groups in Namibia that have completed at least the education levels shown

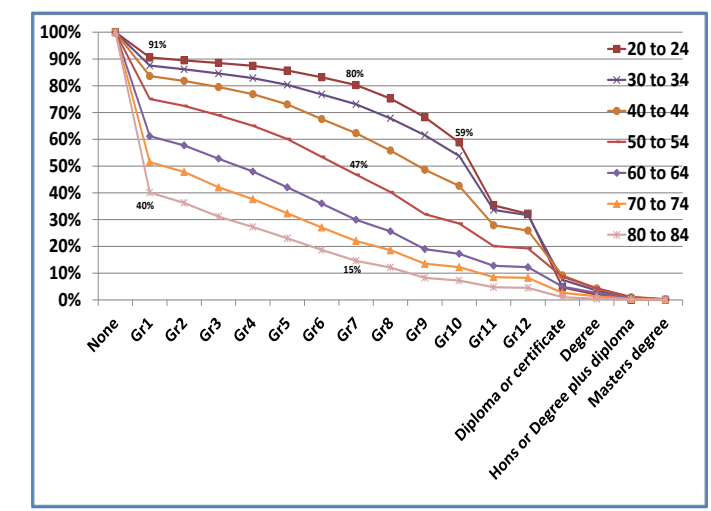

Source: Derived from Namibian Census 2011

Because of the high levels of repetition, gross enrolment rates of $100 \%$ or above can be achieved although many children still do not progress to the highest grades at school. Yet survival to the higher grades has indeed improved.

It is more difficult to forecast numbers in secondary than in primary education, because the survival rates are different. These rates are influenced not only by the demand for education but also by institutional factors such as promotion policies, over-age policies, and examinations that act as an entry gate to certain levels of education. The difficulty level of these examinations in combination with the quality of the education provided may affect how many students qualify to continue to higher levels. In Lesotho and Botswana, Grade 7 pupils write a Primary School Leaving Examination (PSLE) to determine whether they can progress to junior secondary school (Lerotholi, 2001); in Swaziland a similar examination, the Swaziland Primary Certificate Examination, must be passed at the end of Grade 7 before children are eligible to proceed to secondary school (World Bank, 2010; Swazi Legacy, 2011). All the SACU countries except South Africa have country-wide examinations in Grade 10 that affect continuation to the senior secondary grades. In Namibia this examination is combined with age-based limitations on who can repeat, thus influencing dropout from the general education system. Poor quality education in primary school may thus prevent students from proceeding to secondary school; for instance in Lesotho in $2013,12 \%$ of students who wrote the PSLE failed and could therefore not continue to secondary school (Lesotho Times, 2013).

Given the greater obstacles to completion of secondary school (poor quality of education in primary school, daunting entry examinations, and higher opportunity costs for children old enough to get a job), it is likely that the rate of convergence to the long-term asymptote will be slower, and that such an asymptote is likely to be lower than $100 \%$. Thus the projections of completion rates were made as follows, to produce patterns that were broadly reconcilable with recent trends in the SACU countries. It was assumed that both Grade 10 and Grade 12 enrolment would progress towards a maximum of about $91 \%$, but that this maximum is likely to be approached a little faster in the case of Grade 10 . Thus Equations 2 and 3 show that $2.5 \%(1 / 40)$ of the gap between current enrolment and $91 \%$ enrolment would be eliminated every year for Grade 10 and 2\% (1/50) every year for Grade 12.

For Grade 10:

$$
C_{t+1}=C_{t}+\left(0.91-C_{t}\right) / 40
$$

For Grade 12:

$$
C_{t+1}=C_{t}+\left(0.91-C_{t}\right) / 550
$$


This produced the projections shown in Figures $10 \mathrm{D}$ and $10 \mathrm{E}$, and in Table 4 . Once the projections of completion rates had been obtained for the grades shown in Table 4, similar rates were calculated by interpolation for all the other school grades.

Table 4: Projected completion rates for various grades in SACU countries, 2015, 2030, and 2050

\begin{tabular}{|l|l|c|c|c|c|c|}
\hline & & Grade 1 & Grade 5 & Grade 7 & Grade 10 & Grade 12 \\
\hline Botswana & $\mathbf{2 0 1 5}$ & $99.0 \%$ & $96.1 \%$ & $94.6 \%$ & $82.1 \%$ & $49.6 \%$ \\
\hline & $\mathbf{2 0 3 0}$ & $99.5 \%$ & $98.2 \%$ & $97.5 \%$ & $84.6 \%$ & $60.2 \%$ \\
\hline & $\mathbf{2 0 5 0}$ & $99.8 \%$ & $99.3 \%$ & $99.1 \%$ & $87.5 \%$ & $70.1 \%$ \\
\hline Lesotho & $\mathbf{2 0 1 5}$ & $98.6 \%$ & $91.4 \%$ & $82.8 \%$ & $48.1 \%$ & $30.4 \%$ \\
\hline & $\mathbf{2 0 3 0}$ & $99.3 \%$ & $96.0 \%$ & $92.0 \%$ & $61.4 \%$ & $46.0 \%$ \\
\hline & $\mathbf{2 0 5 0}$ & $99.8 \%$ & $98.6 \%$ & $97.1 \%$ & $76.6 \%$ & $60.6 \%$ \\
\hline Namibia & $\mathbf{2 0 1 5}$ & $96.6 \%$ & $93.5 \%$ & $89.9 \%$ & $64.1 \%$ & $39.2 \%$ \\
\hline & $\mathbf{2 0 3 0}$ & $98.4 \%$ & $97.0 \%$ & $95.3 \%$ & $72.3 \%$ & $52.5 \%$ \\
\hline & $\mathbf{2 0 5 0}$ & $99.4 \%$ & $98.9 \%$ & $98.3 \%$ & $81.7 \%$ & $64.9 \%$ \\
\hline South Africa & $\mathbf{2 0 1 5}$ & $99.2 \%$ & $98.3 \%$ & $96.9 \%$ & $82.1 \%$ & $52.9 \%$ \\
\hline & $\mathbf{2 0 3 0}$ & $99.6 \%$ & $99.2 \%$ & $98.6 \%$ & $84.6 \%$ & $62.6 \%$ \\
\hline & $\mathbf{2 0 5 0}$ & $99.9 \%$ & $99.7 \%$ & $99.5 \%$ & $87.5 \%$ & $71.7 \%$ \\
\hline Swaziland & $\mathbf{2 0 1 5}$ & $98.4 \%$ & $94.2 \%$ & $90.0 \%$ & $62.1 \%$ & $41.2 \%$ \\
\hline & $\mathbf{2 0 3 0}$ & $99.2 \%$ & $97.3 \%$ & $95.4 \%$ & $70.9 \%$ & $54.0 \%$ \\
\hline & $\mathbf{2 0 5 0}$ & $99.7 \%$ & $99.0 \%$ & $98.3 \%$ & $81.1 \%$ & $66.0 \%$ \\
\hline
\end{tabular}

\section{From projections of completion rates to projections of school enrolment}

The completion rates discussed above in conjunction with population projections provide the basis for estimating school enrolment for various years. The method is fairly simple: first, an enrolment profile for each birth cohort for each year is derived that will generate the completion rates that were observed in the past or projected into the future, if every year of study is assumed to be successful. Thus, enrolment (and completion, as it is assumed there is no repetition) in year $t$ in Grade 1 will be the Grade 1 completion rate of the birth cohort born in year t- 6 (the cohort of 6 year olds) times the population aged 6; enrolment in Grade 2 will be the Grade 2 completion rate of the birth cohort born in year t-7 times the population aged 7; and so on to enrolment in Grade 12, which will be the Grade 12 completion rate of the birth cohort born in year t-17, times the population aged 17.

Such an enrolment profile will be created if all children enter school at age 6 and there is maximum internal efficiency of the education system, i.e. no repetition. But in reality there is repetition, so the numbers calculated will tend to underestimate actual enrolment. For the SACU countries as a whole, the enrolment numbers calculated for 2012 should be inflated by about $12 \%$ to arrive at the UNESCO estimates of enrolment that were summarized in Table 1, of 14.2 million. Thus all calculated enrolment numbers are inflated by $12 \%$ to estimate enrolment, i.e. assuming a repetition rate of $12 \%$. The projections are made on the assumption that this rate will remain roughly constant over time and that it is the same for all five the SACU countries. This assumption is justifiable because improved quality is likely to reduce repetition over time in the lower grades, but as more children, often from poor backgrounds, continue to higher grades rather than dropping out, repetition in the higher grades is likely to increase. Moreover, as higher cognitive standards are likely to be set in an attempt to improve the quality of education, this will tend to put upward pressure on repetition. 
The projection in Table 5 shows that the pressure on providing places in schools should lessen considerably. The school population for the SACU countries combined is likely to increase at a rate of only $0.3 \%$ per annum in the 15 years from 2015 to 2030, and growth over the longer projected period, 2015 to 2050 , is projected to be around $0.0 \%-$ i.e. no growth. But this average hides some important differences, as it is strongly influenced by the weight of the largest country, South Africa. For the other four SACU countries, the growth rate of the population at school will range between $1.2 \%$ and $2.1 \%$ in the shorter projected period, but over the longer period it will be lower, at $0.4 \%$ to $1.2 \%$. Namibia will experience the fastest growth, as is to be expected, given that its projected population growth is likely to be the fastest and it still has the biggest backlogs of enrolment rates. But even in that country, growth is likely to be far slower than in the past. To put the current growth into perspective, it is useful to consider that in the second half of the previous century, 1950-2000, the average growth rate of school enrolment was $3.7 \%$ for the SACU countries, with three countries (Botswana, Namibia, and Swaziland) having experienced growth of more than $5 \%$ per annum for half a century.

The slowing down of school enrolment has happened for two reasons. The first is that because of demographic change the population of school-going age will be growing fairly slowly: the weighted average for the SACU countries suggests growth of only $0.1 \%$ per year for the next 15 years to 2030, and over the full projection period of 2015-2050 this growth could even be negative, at $-0.2 \%$ per year. Even Namibia, the country with the highest projected population growth for the school-age population, might see growth of only $1.6 \%$ for the shorter period, and less than $1 \%$ per annum over the full period, as demographic change proceeds. The second reason is that all the SACU countries have now reached quite high levels of enrolment.

The projections suggest that the gross enrolment rate for the SACU countries combined will grow only marginally in the next few decades, but that Lesotho, Namibia, and Swaziland are likely to face more challenges in providing resources to meet this growing demand than Botswana and South Africa will.

Somewhat higher or lower gross enrolment rates than those projected here are possible, but the most likely reason for this would be not errors in projecting education demand but higher or lower repetition rates. If repetitions drop below the assumed $12 \%$ on average per grade, enrolment growth may be even lower than projected. However, given generally weak educational quality (discussed further below), it will be difficult to reduce repetition substantially unless the criteria for promotion to the next grade are made less stringent and more students pass the examination at the end of primary school or in Grade 10. This is very unlikely in the shorter projected period. Moreover, the problem of weak educational quality becomes even worse as more children reach the secondary grades, where earlier learning deficits are likely to be binding. 
Table 5: School enrolment and projections, 1950 to 2050

\begin{tabular}{|c|c|c|c|c|c|c|}
\hline & 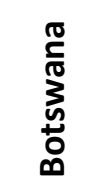 & 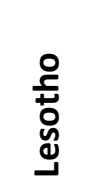 & $\frac{\frac{\pi}{0}}{\frac{\varepsilon}{\frac{\delta}{\pi}}}$ & 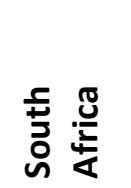 & 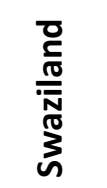 & 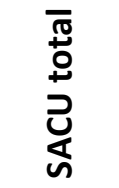 \\
\hline & \multicolumn{6}{|c|}{ School age population } \\
\hline 1950 & 123 & 203 & 127 & 3648 & 78 & 4179 \\
\hline 2000 & 525 & 578 & 561 & 12,051 & 368 & 14,084 \\
\hline 2015 & 540 & 591 & 663 & 12,585 & 362 & 14,742 \\
\hline 2030 & 633 & 663 & 844 & 12,454 & 407 & 15,001 \\
\hline 2050 & 597 & 648 & 911 & 11,411 & 396 & 13,963 \\
\hline Growth rate $2015-2030$ per annum & $1.1 \%$ & $0.8 \%$ & $1.6 \%$ & $-0.1 \%$ & $0.8 \%$ & $0.1 \%$ \\
\hline \multirow[t]{2}{*}{ Growth rate $2015-2050$ per annum } & $0.3 \%$ & $0.3 \%$ & $0.9 \%$ & $-0.3 \%$ & $0.3 \%$ & $-0.2 \%$ \\
\hline & \multicolumn{6}{|c|}{ School enrolment (assuming no repetition) } \\
\hline 1950 & 24 & 67 & 38 & 1,777 & 21 & 1,928 \\
\hline 2000 & 434 & 379 & 424 & 10,464 & 283 & 11,985 \\
\hline 2015 & 475 & 439 & 537 & 11,226 & 295 & 12,973 \\
\hline 2030 & 574 & 548 & 731 & 11,394 & 352 & 13,599 \\
\hline \multirow[t]{2}{*}{2050} & 556 & 574 & 827 & 10,662 & 359 & 12,977 \\
\hline & \multicolumn{6}{|c|}{ School enrolment (assuming $12 \%$ repetition) } \\
\hline 1950 & 27 & 75 & 42 & 1,990 & 24 & 2,159 \\
\hline 2000 & 486 & 425 & 475 & 11,720 & 317 & 13,423 \\
\hline 2015 & 532 & 492 & 602 & 12,574 & 330 & 14,530 \\
\hline 2030 & 643 & 614 & 818 & 12,761 & 395 & 15,231 \\
\hline 2050 & 623 & 643 & 926 & 11,941 & 402 & 14,535 \\
\hline Growth rate $2015-2030$ per annum & $1.3 \%$ & $1.5 \%$ & $2.1 \%$ & $0.1 \%$ & $1.2 \%$ & $0.3 \%$ \\
\hline \multirow[t]{2}{*}{ Growth rate $2015-2050$ per annum } & $0.4 \%$ & $0.8 \%$ & $1.2 \%$ & $-0.1 \%$ & $0.6 \%$ & $0.0 \%$ \\
\hline & \multicolumn{6}{|c|}{ Gross enrolment } \\
\hline 1950 & $22 \%$ & $37 \%$ & $33 \%$ & $55 \%$ & $31 \%$ & $52 \%$ \\
\hline 2000 & $93 \%$ & $73 \%$ & $85 \%$ & $97 \%$ & $86 \%$ & $95 \%$ \\
\hline 2015 & $99 \%$ & $83 \%$ & $91 \%$ & $100 \%$ & $91 \%$ & $99 \%$ \\
\hline 2030 & $102 \%$ & $93 \%$ & $97 \%$ & $102 \%$ & $97 \%$ & $102 \%$ \\
\hline 2050 & $104 \%$ & $99 \%$ & $102 \%$ & $105 \%$ & $102 \%$ & $104 \%$ \\
\hline
\end{tabular}

Source: Own estimates based on combining information and projections on grade completion rates derived from survey and census data and information from the UN Population Division population projections

\section{Enrolment in tertiary education}

Enrolment in tertiary education is strongly influenced by secondary education completion rates, but also by a very rapid growth in the demand for tertiary education as an economy develops. However, tertiary education, like TVET (technical and vocational education and training), is subject to much institutional diversity even within countries, and more so between countries, making comparisons difficult. Also, tertiary education is initially relatively undeveloped in poor and even middle income countries, so the growth of enrolment at this level takes place from a very low base. For instance, in the SACU countries around 1980, the proportion achieving degrees ranged from only $2.5 \%$ in Lesotho to $8 \%$ in Botswana. Similar numbers may be involved in other forms of tertiary education, but these are difficult to define clearly: they often include many diverse forms of training with varying qualifications and entry requirements attached to them. 
As the number of students completing Grade 12 in the SACU countries continues to rise, the pressure to provide more places in tertiary education facilities is likely to increase. However, whereas the pressure to provide more places in schools has largely been accommodated in all the SACU countries, providing tertiary places is likely to be much more of a problem. This is partly because tertiary education tends to cost more than school education, and partly because tertiary level staff are in short supply and tertiary institutions have to compete with other employers in the private and the public sector for qualified personnel.

\section{Implications of the education demand projections}

\section{The supply of education: Quantitative issues}

The rising demand for school education has slowed, partly because the SACU countries have already moved closer to full enrolment, and partly because demographic pressure has also eased. Thus the need for additional teachers should also slow, except where it is necessary to reduce excessively high pupil-teacher ratios. However, the imminent retirement of many teachers appointed during the rapid expansion phases of the school system means that large numbers of qualified people will still have to be drawn into teaching in the projected periods.

A latent demand that has been inadequately met in the past decades is for tertiary education. Unlike the case of school enrolment, tertiary enrolment largely reflects supply rather than demand constraints. Meeting this demand is likely to become more difficult in future, as the new generations of students leaving schools have greater expectations in this regard.

\section{Implications for public finance}

Following Colclough and Al Samarrai (2000: 1029), e, the recurrent cost of school education relative to $\mathrm{GNP},{ }^{10}$ is a function of the gross enrolment rate $g$, the population of school-going age $a$, and the cost per unit of delivering education as a proportion of per capita GNP, c. Thus

$$
\mathrm{e}=\mathrm{g} \cdot \mathrm{a} \cdot \mathrm{c}
$$

(Equation 4)

This demonstrates that the pressure on public finance resources is increased by the demand for education (as reflected in the gross enrolment rate g), demography (as reflected in the proportion of the population of school-going age, a), and the unit cost of education, $c$. Fortunately, demographic pressure is weakening, with the proportion of the population that is of school-going age declining in all five SACU countries (see Table 6). In four of the countries the number of children of school-going age is set to rise to 2030, albeit not greatly in Swaziland $(12 \%)$, Lesotho (12\%), and Botswana (17\%), but more substantially in Namibia (27\%). For South Africa a very slight decline is projected. Between 2030 and 2050, all the SACU countries except Namibia can expect a decline in the numbers of children of school-going age. The school-going age group is set to decline in all five countries over the full period, indicating less fiscal pressure from this source if the economies of these countries grow in line with or faster than the population.

\footnotetext{
${ }^{10}$ We follow Colclough and Al Samarrai in using GNP rather than GDP. In many countries the difference between these is small, but it is likely to be larger in the SACU countries because of labour migration.
} 
Table 6: School-age and total population projections

\begin{tabular}{|l|r|r|r|r|}
\hline & $\begin{array}{c}\text { School-age } \\
\text { population } \\
\text { (6-17 years) } \\
\text { '000s }\end{array}$ & $\begin{array}{c}\text { \% of 2015 } \\
\text { number }\end{array}$ & \multicolumn{1}{c|}{$\begin{array}{c}\text { Total } \\
\text { population } \\
\text { '000s }\end{array}$} & $\begin{array}{c}\text { School-age } \\
\text { population as } \\
\text { \% of total }\end{array}$ \\
\hline Botswana 2015 & 540.3 & $100 \%$ & $2,262.5$ & $23.9 \%$ \\
\hline Botswana 2030 & 633.5 & $117 \%$ & $2,818.1$ & $22.5 \%$ \\
\hline Botswana 2050 & 597.0 & $110 \%$ & $3,390.0$ & $17.6 \%$ \\
\hline Lesotho 2015 & 590.9 & $100 \%$ & $2,135.0$ & $27.7 \%$ \\
\hline Lesotho 2030 & 662.8 & $112 \%$ & $2,487.2$ & $26.6 \%$ \\
\hline Lesotho 2050 & 648.2 & $110 \%$ & $2,988.2$ & $21.7 \%$ \\
\hline Namibia 2015 & 663.2 & $100 \%$ & $2,458.8$ & $27.0 \%$ \\
\hline Namibia 2030 & 843.8 & $127 \%$ & $3,272.2$ & $25.8 \%$ \\
\hline Namibia 2050 & 910.9 & $137 \%$ & $4,321.6$ & $21.1 \%$ \\
\hline South Africa 2015 & $12,585.3$ & $100 \%$ & $54,490.4$ & $23.1 \%$ \\
\hline South Africa 2030 & $12,453.5$ & $99 \%$ & $60,034.4$ & $20.7 \%$ \\
\hline South Africa 2050 & $11,411.0$ & $91 \%$ & $65,539.5$ & $17.4 \%$ \\
\hline Swaziland 2015 & 362.1 & $100 \%$ & $1,287.0$ & $28.1 \%$ \\
\hline Swaziland 2030 & 407.4 & $112 \%$ & $1,506.7$ & $27.0 \%$ \\
\hline Swaziland 2050 & 395.7 & $109 \%$ & $1,792.2$ & $22.1 \%$ \\
\hline
\end{tabular}

Source: United Nations Population Division, Population Prospects 2015 Revision

It is likely that a growing demand for school education, as proxied by a rising gross enrolment rate, will tend to raise fiscal pressure. In addition, with more children progressing to secondary school there is likely to be pressure for the unit cost of providing education to rise, because of the smaller classes, greater subject specialization, and higher qualified teachers than are needed in primary school. On the other hand, as a country develops, teachers' salaries tend to rise less than the average (Colclough and Al Samarrai, 2000); teachers initially form part of a small educated elite that is generally well paid, but in a more sophisticated economy there would be more highly educated persons in other sectors too, and they would often earn more than teachers.

Summing up, while rising gross enrolment rates and demographic change will exert increasing fiscal pressure, the effect of the cost per student depends on factors with opposing implications: the demand for more expensive secondary and tertiary education will increase costs, but the likely relatively lower costs of employing teachers works in the opposite direction.

In all the SACU countries, the educational expansion of the 1980s and 1990s has meant that large numbers of teachers will soon be reaching retirement age. Though that demographic trend is not central to this study, it is something to consider when planning for their replacement; in at least some countries this will require a strong expansion of teacher training to cope with both retirement and the continuing growth of especially secondary education. This may necessitate policies to keep teacher salaries attractive, as well as training policies and scholarships to attract good candidates into teaching.

Funding university, college, and TVET education is another matter, though. The need for these will increase as the economy develops, and as more and more students complete grades from which they can move into higher education or TVET. The unit cost of such training is many multiples of the unit cost of school education. Moreover, for the four smaller SACU countries in terms of population (Botswana, Lesotho, Namibia, and Swaziland all have a population size well below 3 million), it would be very costly to introduce a full range of specialist training in 
universities, colleges and TVET institutions. Thus there is a need to investigate shared training facilities through agreement within the SACU countries.

\section{The quality of education}

The five SACU countries all participated in SAQMEQ III, the international school testing program carried out by the Southern and Eastern African Consortium for Monitoring Educational Quality in Grade 6 in 2007. The SACMEQ mean, set to 500 in SACMEQ II with the standard deviation set to 100 , rose to slightly higher levels in SACMEQ III. Within SAQMEQ the performance of the SACU countries was about average (Figure 13A), with Swaziland performing almost half a standard deviation above average and Lesotho about one-third of a standard deviation approximately one year of learning - below average.

While the reading score for the SACMEQ countries was on average 512 in 2007 (Figure 13A), for the poorest quarter of the students (as reflected in their socio-economic status based on assets at home) attending school (Figure 13B) it was only 481. This difference of 31 points ( 0.31 of a SACMEQ standard deviation) is equivalent to almost one year of learning. The difference between the average scores and the scores of the poorest quarter of students varied from country to country: only 17 points in Swaziland and 19 points in Lesotho, but 39 points in Namibia, 68 points in Botswana, and a very high 72 points in South Africa.

Figure 13: Reading scores of southern and eastern African countries in Grade 6 in SACMEQ III, 2007

\section{A: Reading score - all}

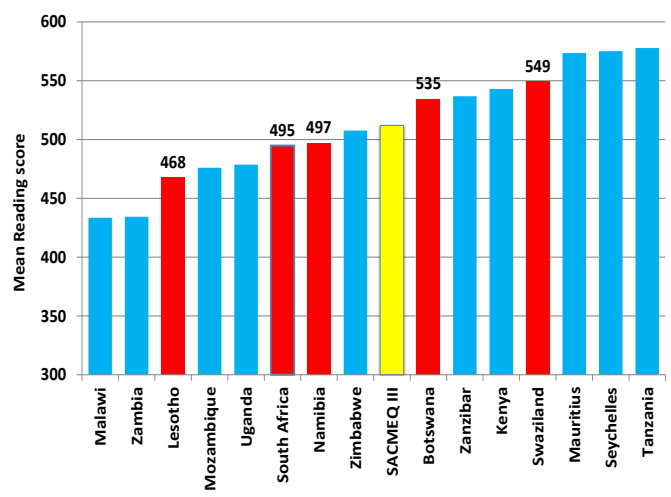

B: Reading score - poorest quarter of students based on assets at home

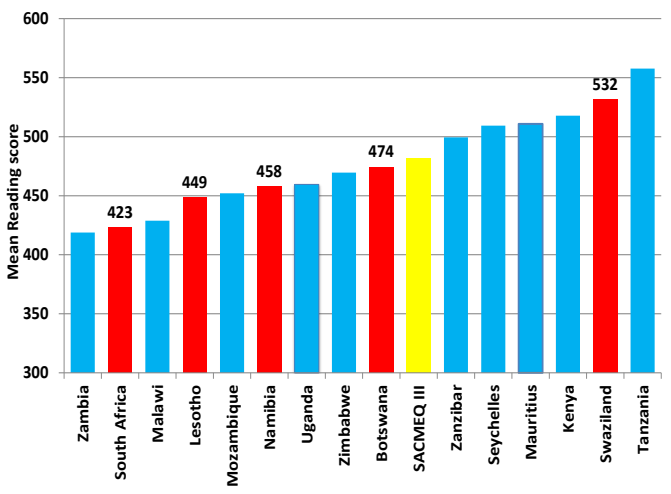

Note: Scores calibrated to set SACMEQ II mean in 2001 at 500 and standard deviation at 100

Only South Africa and Botswana have participated in other international educational evaluations. However, it is possible to use the performance of those countries that participated in TIMSS and PIRLS to calibrate the performance of all the other SAQMEQ countries in terms of international evaluations. Although the international comparisons undertaken by Hanushek and Woessmann $(2008,2009)$ and Hanushek and Zhang (2009) did not include the SAQMEQ countries, Gustafsson (2014) has extended this work using a non-linear programing procedure. The results of this comparison are shown in Figure 14. On the PISA scale, where the average 2000 PISA performance was set at 500 and the standard deviation across the whole sample at 100, Lesotho (288), Namibia (289), and South Africa (314) score extremely low, with Botswana (367) and Swaziland (388) performing somewhat better, but still more than 1 standard deviation below the PISA mean. Figure 14 shows international cross-country performance on this PISA scale with the level of GDP per capita on the x-axis, with the scores of the SACU countries identified. All five SACU countries perform below expectation, given their development level, thus placing them below the international trend line. Namibia, South Africa and Lesotho in particular perform far below expectations. 
Figure 14: Country performance in international educational evaluations in PISA metrics by per capita GDP (PPP\$), around 2011

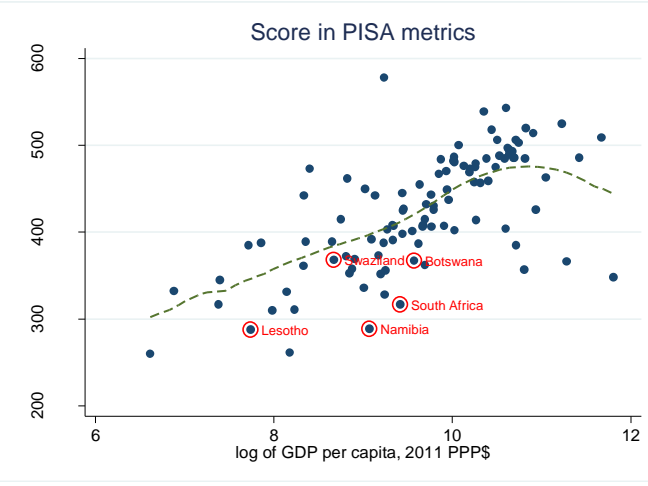

Source: Based on Gustafsson (2014)

In 2011, Botswana was the only one of the SACU and indeed also the SACMEQ countries that participated in the PIRLS/TIMSS joint survey of reading, mathematics, and science. These tests are usually carried out in Grade 4, but because of previous weak performance in other tests, Botswana students wrote these tests in Grade 6. Table 7 and Figure 15 show the results for a sample of the 34 countries that participated, in terms of performance at two levels, the first being the high international benchmark ( 550 points) and the second the low international benchmark ( 400 points, where 500 is again the reference mean and 100 the standard deviation).

The table and the figure show that Botswana's performance is far below levels that are commonly seen in most developed and even middle income countries. Whereas more than $90 \%$ of Grade 4 children in many countries perform above the low international benchmark, only $37 \%$ of Grade 6 children in Botswana achieve this; and while more than $20 \%$ of Grade 4 children in the leading countries perform above the high international benchmark in all three subjects, only $3 \%$ of Botswana Grade 6 children perform above the international benchmarks in all three subjects. 
Table 7: Performance in joint PIRLS/TIMSS tests, 2011

\begin{tabular}{|c|c|c|c|c|c|c|c|c|}
\hline & \multicolumn{4}{|c|}{$\begin{array}{c}\% \text { who reach high international } \\
\text { benchmark ( } 550)\end{array}$} & \multicolumn{4}{|c|}{$\begin{array}{c}\% \text { who reach low international } \\
\text { benchmark (400) }\end{array}$} \\
\hline & 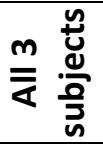 & 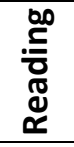 & $\begin{array}{l}n \\
\frac{n}{n} \\
\sum\end{array}$ & 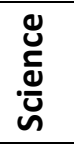 & 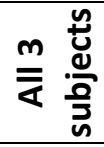 & 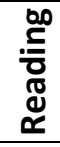 & $\begin{array}{l}n \\
\sum_{n}^{ \pm} \\
\sum \\
\Sigma\end{array}$ & 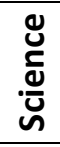 \\
\hline Australia & 22 & 42 & 35 & 36 & 86 & 93 & 91 & 92 \\
\hline Czech Republic & 21 & 50 & 30 & 45 & 92 & 98 & 93 & 96 \\
\hline Slovak Republic & 21 & 44 & 30 & 44 & 89 & 96 & 91 & 94 \\
\hline Lithuania & 21 & 39 & 43 & 31 & 92 & 97 & 96 & 95 \\
\hline Italy & 18 & 46 & 28 & 37 & 90 & 98 & 93 & 95 \\
\hline Sweden & 18 & 47 & 25 & 44 & 91 & 98 & 93 & 95 \\
\hline Romania & 17 & 32 & 28 & 37 & 73 & 86 & 79 & 84 \\
\hline Poland & 12 & 39 & 17 & 29 & 83 & 95 & 87 & 91 \\
\hline Spain & 9 & 30 & 17 & 28 & 82 & 94 & 87 & 92 \\
\hline UAE & 6 & 14 & 12 & 14 & 48 & 64 & 64 & 61 \\
\hline Iran & 4 & 13 & 9 & 16 & 57 & 76 & 64 & 72 \\
\hline Azerbaijan & 3 & 9 & 21 & 13 & 55 & 82 & 72 & 65 \\
\hline Saudi Arabia & 2 & 8 & 7 & 12 & 43 & 65 & 55 & 63 \\
\hline Botswana (Gr.6) & 3 & 9 & 7 & 7 & 37 & 56 & 60 & 43 \\
\hline Honduras (Gr.6) & 2 & 11 & 3 & 8 & 43 & 74 & 49 & 60 \\
\hline Morocco (Gr.6) & 0 & 1 & 2 & 1 & 8 & 21 & 26 & 15 \\
\hline
\end{tabular}

Note: Tests were taken in Grade 4 in all countries, except for the last three shown here, where testing was done in Grade 6.

Source: Martin and Mullis, 2013

Figure 15: Botswana's performance in joint PIRLS/TIMSS tests in comparison, 2011

A: Score categories in all 3 subjects jointly (\%) B: Score categories in Reading (\%)

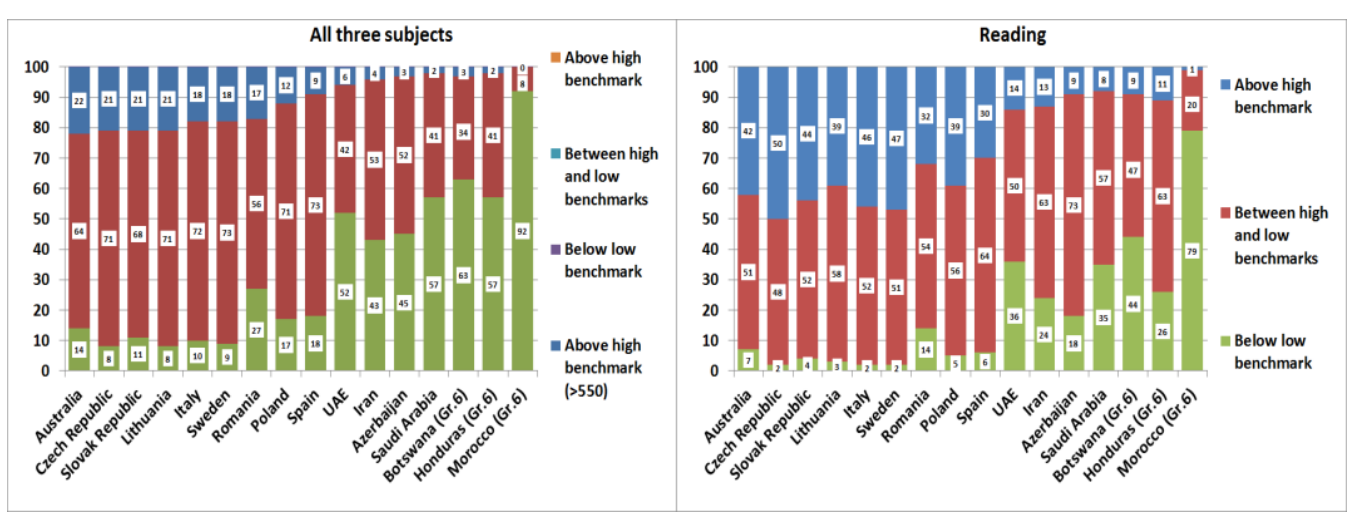




\section{C: Score categories in Mathematics (\%) B: Score categories in Science (\%)}

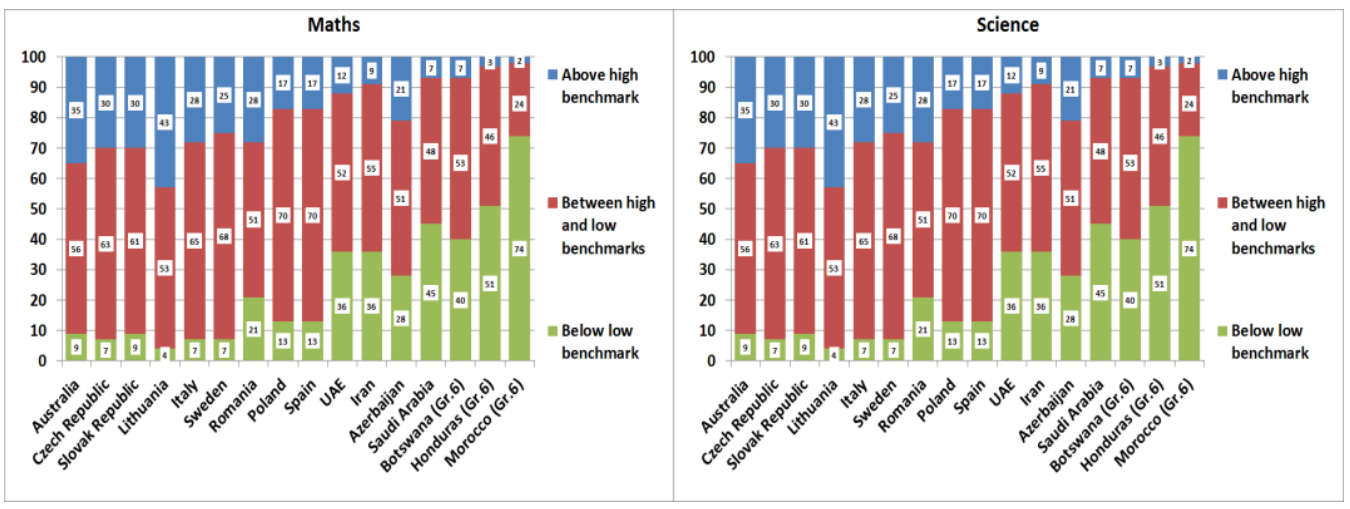

Given that Botswana is the second best performer in the SACU countries both in the SACMEQ tests and in Gustafsson's PISA-calibrated estimates, these results indicate that a very small proportion of children in all five SACU countries perform at or above the low international benchmark. The labor force in the SAQMEQ countries would need to be endowed with far greater skills in order to be internationally competitive in terms of cognitive development. This also has severe implications for higher levels of university and technical and vocational education.

Figure 16 presents another way of illustrating the weak performance of SACU countries in international evaluations. It shows the cumulative density curve of scores of South African children against those of children from England on the 2006 PIRLS tests, a reading and literacy test written in 2006. South African children were tested in Grade 5, English children in Grade 4. Even so, the South African children are far behind their counterparts: only $8 \%$ of English children could not reach the low international benchmark of 400 , but a massive $78 \%$ of South African children failed to reach it. Of the English children, 70\% reached at least the international set point (the average across participating countries) of 500 , but this was achieved by only $9 \%$ of South African children.

Figure 16: Cumulative proportion of children from South Africa and England scoring below each score level shown in PIRLS 2006

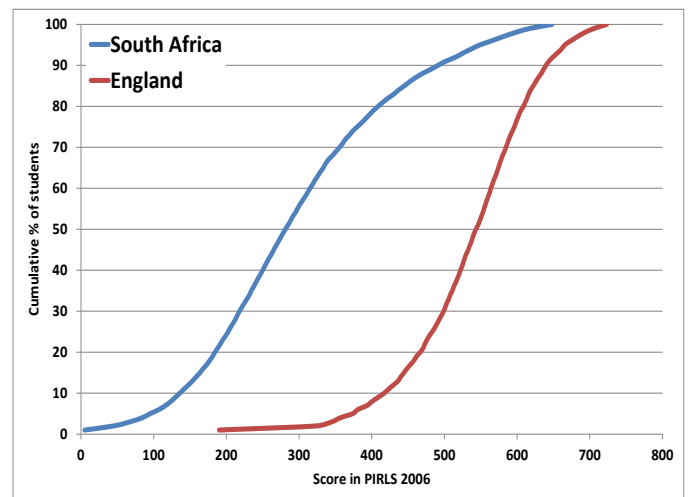

Note: First Plausible Value (PV1) in PIRLS dataset used. South African children were tested in Grade 5, English children in Grade 4.

These examples illustrate the weak performance of children from SACU countries in international cognitive tests. Further examples from Botswana's and South Africa's participation in the Grade 8 or 9 TIMSS tests confirm this for mathematics and science. 


\title{
How much quality improvement is feasible?
}

If education quality is deficient in the SACU countries, how feasible are large gains in such quality over time? Mourshed et al. (2010: 16, in Gustafsson, 2014) believe a good yet attainable trend over ten years is 1 PISA point, or 0.01 PISA standard deviation, per year, but their results are based mainly on a sample of developed countries, where gains are less likely because of diminishing marginal returns. Hanushek and Woessman (2008) believe that in a program such as TIMSS, an improvement of half a standard deviation (50 points) is possible in 10 to 30 years, i.e. between 2 and 5 PISA points or 0.02 and 0.05 standard deviations a year. Gustafsson finds an average improvement of only 0.8 PISA points per year across a large number of cases, but a much higher 3 PISA points per years for non-OECD countries. He notes that although improvements of as much as 20 PISA points per year appear possible, they are rare. The best consistent average annual improvements he found were for Brazil (5.9 PISA points per year) and Chile (4.5 points). He concludes that

\begin{abstract}
if the diminishing marginal rate of improvement is taken into account a simulation would indicate that it would take exceedingly long for developing countries to catch up. South Africa, for instance, would require 160 years to reach the levels found in non-Asian OECD countries. For Brazil the duration would be around 130 years. Clearly the mean rates of improvement seen in the data are discouragingly low. (Gustafsson, 2014:132)
\end{abstract}

From the discussion above, it seems it will take many years for the SACU countries to reach average PISA levels of educational quality, i.e. to achieve around 500 points on the PISA scale or equivalent.

\section{Implications for economic growth}

In the economic growth literature, education is often included as an explanatory variable. However, the strength of the statistical relationship between education and growth depends largely on how education is measured and what other variables are also controlled for in such regressions, as education is closely correlated with many other social measures associated with economic growth. Hanushek and Woessmann $(2008,2009)$ have shown that the growth effect of education is considerably enhanced if education is measured by both its quantity and its quality (cognitive skills). In contrast, Patrinos and Psacharopoulos (2011: 18) investigate the effect of educational attainment and conclude that a one-year increase in average years of education of the adult population is associated with about $35 \%$ higher per capita income, a figure similar to the $30 \%$ found by Heckman and Klenow (1997), who ascribe the largest part of this benefit to human capital externalities rather than to individual returns to education.

\section{The need for an appropriate education mix}

The rise in the demand for education, met by a sufficient supply of education, would mean that the labor force of the five SACU countries would soon reach levels of education that were reached by many developed countries only a few decades ago. Taking an optimistic view, this could be expected to make a major contribution to economic growth through the higher labor productivity that this would induce.

However, rising education levels and urbanization may also give young people entering the labor market greater expectations. To meet these expectations requires that the economy should experience strong growth and labor absorption. Also, for the young people to earn higher incomes would require that the education should be of good quality and that appropriate specific skills of the type required for a modern economy should be provided. In Swaziland, Brixiova, and Kangoye (2013:12) note that "evidence of skill mismatches has emerged, with the young educated job seekers not having skills demanded by employers (e.g., business, technical, 
ICT skills)." The needs of the economy for specific technical skills means that not only general education but also TVET is essential.

Vocational education is designed to give students the knowledge, skills and competencies specific to a particular occupation or trade. It often has work-based components (e.g. apprenticeships). If successful, such programs lead to labor market relevant vocational qualifications. In the SACU countries, small numbers of students currently take part in vocational training and the sector still needs to develop and mature. In Namibia, vocational training is largely decoupled from the school system, but often some TVET can take place alongside general education in schools. In secondary school in Lesotho it is possible to choose a stream of technical or vocational training instead of general secondary education (SACMEQ, 2015a), and in Swaziland and Botswana vocational training is an option after Grades 10 (UNESCO and IBE, 2010a, 2010b).

According to UIS data, the share of upper secondary students in vocational or technical education amounts to only $9 \%$ in South Africa, $11 \%$ in Lesotho, and $15 \%$ in Botswana. To put this in context, the figure in Ghana is also only $9 \%$, but it is $35 \%$ in Chile and $51 \%$ in Australia.

Apart from the need to expand enrolment, the TVET system in the SACU countries faces challenges that may thus far have limited the demand for such education. The training that the TVET programs offer tends to be supply driven and therefore out of touch with market needs, and its quality often leaves much to be desired. The World Bank (2010) says that in Swaziland "courses offered by both formal and non-formal providers focus on traditional entry level skills such as mechanics, automotive, electrical, building, commerce and sewing. They do not adequately cater to emerging areas such as: services, tourism, childcare, healthcare and higherlevel technician skills". In Lesotho, too, the emphasis has fallen on non-technical education; this has led to a lack of the skills that match labor market demands (African Economic Outlook, 2015).

Often, as is the case in Botswana, businesses view the training provided by the TVET system as outdated and inadequate for the job market realities. For example, mechanical, engineering, and ICT graduates of technical institutions suffer high unemployment because the quality of their skills is questioned (World Bank, 2014a). In Swaziland, companies struggle to find properly trained mechanical, electrical, electronic, and computer technicians. Such individuals often have to be retrained as the quality of their education does not meet employers' expectations (World Bank, 2014b). In South Africa, too, Further Education and Training (FET) colleges are perceived to be substandard and many fail to attract qualified lecturers, thus such colleges are often viewed as the option of last resort. However, artisan and technical studies (building, boilermaking, plumbing, and electrical studies) are said to be having a positive impact (Nkosi, 2012).

Even the university education provided in the SACU countries needs to be better targeted at economic needs. The percentage of tertiary graduates from science programs is low in some SACU countries - Lesotho and Namibia around 1\%, Swaziland 2\%, Botswana 9\%, and South Africa $11 \%$. This contrasts with even a lower-middle income country such as El Salvador, where the figure is $12 \%$, though the figures for Brazil, Chile, and Mexico (all at $5 \%$ ) and the US (9\%) are not as high. ${ }^{11}$ For 2008-2010, African Economic Outlook (2012) reports that engineering, manufacturing, and construction graduates from universities in Africa constituted only $4 \%$ of all graduates, as against 20\% from Asia, $11 \%$ from the OECD countries and $9 \%$ from Latin America.

Policy makers in the SACU countries will have to pay particular attention to the nature and quality of the education they provide, given resource constraints and the needs of a modern

\footnotetext{
${ }^{11}$ Generally, field of study figures (SARUA, 2012) do not show the extent to which African countries are under-investing in technical fields such as science and engineering compared to other parts of the world.
} 
economy. One problem that will have to be faced results from the small size of the population and economies of four of the SACU countries. As indicated earlier, specialized skills are difficult and costly to provide, and unless economies of scale are harnessed they will be too costly for these countries to afford. Thus there is an urgent need to consider offering some vocational and technical training and even specialized degree programs jointly for two or more SACU countries. Moreover, unless the quality of TVET is good and it offers attractive labor market prospects, the preference of students for general education at both school and tertiary levels is likely to remain, with negative consequences for the economies of the SACU countries.

\section{Conclusions and some policy considerations}

In this paper the implications of demographic change for education were considered from a perspective that emphasized the demand for education. A few conclusions can be drawn from this study that have implications for the SACU countries jointly, although some also have specific implications for the individual countries. The conclusions are briefly set out below.

- Demographic prospects are for the school-age population to grow fairly slowly over the projected periods. This immediately reduces a potential source of budgetary pressure.

- The demand for education will nevertheless increase beyond this, but the gross enrolment rate - school enrolment relative to the school-age population - will grow only moderately, from about $99 \%$ to $104 \%$ for the five SACU countries jointly over the full 35 -year period (2015-2050). But three SACU countries - Lesotho, Namibia, and Swaziland - will experience much more rapid demand and thus enrolment growth.

- Generally, strong fiscal pressure for expanding school education will abate, allowing possibilities for intensification of spending. This can take various forms, but it is important to keep teacher salaries in check so that this fiscal space can be used largely to improve teacher-pupil numbers where these are high, or to add more complementary resources. Pritchett and Filmer (1999) have shown that, in terms of allocative efficiency, the international empirical literature can be interpreted as implying that more spending is warranted on complementary resources than on more teacher resources.

- Despite modest growth in enrolment, teacher training needs to remain high on the agenda. This is because many teachers who entered the labor force during the rapid expansions of the 1980s and 1990s will soon be retiring and will need to be replaced. Competition for qualified personnel from other sectors of the economy is likely to intensify, thus teacher salaries may need to be high to prevent large outflows of teachers into other jobs. In addition, training needs to be directed at improving teacher skills, considering the poor quality of much of the education in the region.

- Education quality is currently extremely weak in the SACU countries and major improvement is urgently needed. This requires attention to teacher skills, but also to the creation of an education system with strong accountability features and enough testing of cognitive skills to ensure improvement in teaching and learning.

- Although the benefits of general education are widely acknowledged, for the growth and development of the SACU countries and to meet the needs of their population and a modern economy, it is imperative that enough specialized and appropriate skills be developed. This will require stronger emphasis on technical and vocational education and training (TVET), but it must be alongside and following on school education. In addition, care should be taken to ensure that enough university students graduate with the skills needed for a modern economy.

- While the fiscal pressures on school education are easing, the need for rapid expansion of tertiary education and TVET will place increasing pressure on the budget, particularly as this part of education provision is more costly per unit. The latent demand for tertiary education is extremely high and current capacity to provide such education is limited. How to fund 
tertiary education is likely to be an important issue for the SACU countries over the projected period. While the demand for TVET is not yet as developed, because of past poor quality and consequent low returns to such education and training, the needs of the economy require that this be expanded rapidly, but in a way that responds to market needs rather than being supply driven.

- Both tertiary education and TVET require skilled and specialized personnel. Such personnel are in short supply, and providing specialized training for small economies with small numbers of inhabitants is often not financially viable. It is therefore imperative that attention be given to collaborative SACU efforts in this regard. 


\section{REFERENCES}

African Economic Outlook. 2012. Promoting youth employment. http://www.africaneconomicoutlook.org/en/ [Accessed 3 Aug. 2015].

African Economic Outlook. 2015. Lesotho 2015. http://www.africaneconomicoutlook.org/en/ [Accessed 3 Aug. 2015].

Bailey T, Cloete N \& Pillay, P. 2011. Higher Education and Economic Development in Africa: Case Study - Botswana and University of Botswana. Cape Town: Centre for Higher Education and Training.

Brixiova, Zuzana and Kangoye, Thierry. 2013. Youth employment in Africa: New evidence and policies from Swaziland. IZA Discussion Papers 7467. Bonn: Institute for the Study of Labor (IZA)

Chenery, Hollis and Syrquin, Moises. 1975. Patterns of development, 1950-1970. London: Oxford University Press.

Chenery, Hollis. 1979. Structural change and development policy. London: Oxford University Press.

Colclough, Christopher and Al Samarrai, Samer. 2000. Achieving schooling for all: Budgetary expenditures on education in sub-Saharan Africa and South Asia. World Development 28(11): 1927-1944

Da Maia, Carlos. 2012. Understanding poverty and inequality in Mozambique: The role of education and the labour market. PhD Thesis. Stellenbosch: University of Stellenbosch

Pritchett, L. and Filmer, D. 1999. What education production functions really show: a positive theory of education expenditures. Economics of Education Review 18(2): 223-239.

Glewwe, Paul and Jacoby, Hanan G. 2004. Economic growth and the demand for education: is there a wealth effect? Journal of Development Economics 74(1): 33-51

Gustafsson, Martin A. 2014. Education and country growth models. PhD Thesis. Stellenbosch: University of Stellenbosch

Hanushek, Eric and Woessmann, Ludger. 2008. The role of cognitive skills in economic development. Journal of Economic Literature 46 (3): 607-668

Hanushek, Eric and Woessmann, Ludger. 2009. Do better schools lead to more growth? Cognitive skills, economic outcomes, and causation. NBER Working Paper 14633. Cambridge, Mass: National Bureau of Economic Research.

Hanushek, Eric and Zhang, L. 2009. Quality-consistent estimates of international schooling and skill gradients. Journal of Human Capital 3 (2): 107-143

Heckman, J. 2007. The economics, technology, and neuroscience of human capability formation. NBER Working paper 13195.

Heckman, James and Klenow, Pete. 1997. Human capital policy. Unpublished manuscript: University of Chicago. (http://klenow.com/HumanCapital.pdf).

Heckman, J., and Masterov, D. V. 2007. The productivity argument for investing in young children. Institute for the Study of Labor (IZA), Discussion Paper No. 2725.

Lerotholi, L.M. 2001. Tuition fees in primary and secondary education in Lesotho: the levels and implications for access, equity and efficiency. Available at http://unesdoc.unesco.org/images/0012/001235/123535e.pdf [Accessed 21 Sept. 2015].

Lesotho Times. (2013). PSLE results out. Lesotho times: 28 November 2013. Available at http://lestimes.com/psleresults-out/. [Accessed: 3 October 2015].

Martin, M.O. and Mullis, I.V.S. (Eds.). 2013. TIMSS and PIRLS 2011: Relationships among reading, mathematics, and science achievement at the fourth grade-Implications for early learning. Chestnut Hill, MA: TIMSS and PIRLS International Study Center, Boston College. Ch.1 by Ina V.S. Mullis: Profiles of achievement across reading, mathematics, and science at the fourth grade. http://timssandpirls.bc.edu/timsspirls2011/downloads/TP11 Chapter 1.pdf

Mussa, Richard. 2009. Children, investments in education and poverty in Malawi. PhD thesis: Cape Town: University of Cape Town.

Namibia, National Planning Commission. 2012. Namibia's fourth National Development Plan. Windhoek: NPC.

NPC Namibia. 2012a. National Human Resources Plan: 2010 - 2025. [online]. Available at: http://www.npc.gov.na/?wpfb dl=203 [Accessed on 3 Aug. 2015].

Nkosi, B. 2012. Why students fret at the thought of FET. http://mg.co.za/article/2012-01-20-why-students-fret-atthough-of-fet [Accessed 3 Aug. 2015].

Patrinos, Harry Anthony and Psacharopoulos, George, 2011. Education : Past, present and future global challenges. Policy Research Working Paper Series 5616. Washington, DC: World Bank.

SARUA (Southern African Regional Universities Association). 2012. A profile of higher education in Southern Africa. http://www.sarua.org/files/publications/SARUA\%20leadership\%20Dialogue\%20Series/SARUA\%20Profiles \%20of\%20HE\%20Vol\%202.pdf [Accessed 3 Aug. 2015].

Siphambe, H. \& Motswapong, M. 2011. Female participation in the labour market of Botswana: Results from the 2005/06 labour force survey data. Botswana Journal of Economics 7: 64-77

Stiglitz, J.E. 1974. The demand for education in public and private school systems. Journal of Public Economics 1974(3): 349-385.

Swazi Legacy (2011). Education System in Swaziland. http://www.swazilegacy.org/swaziland/education.html [Accessed 21 Sept. 2015]. 
Spaull, N. and Taylor, S. 2015. Access to what? Creating a composite measure of educational quantity and educational quality for 11 African countries. Comparative Education Review 58(1): 133-165.

UNESCO and IBE (2010a). World Data on Education: Swaziland.

UNESCO and IBE (2010b). World Data on Education: Botswana. [online]. Available at

UNESCO Institute for Statistics (UIS) (2014). Country Profiles. http://uis.unesco.org/DataCentre/Pages/countryprofile.aspx?code=LSO [Accessed 21 Sept. 2015].

UNICEF. 2015: UNICEF Eastern and Southern African Region. http://www.unicef.org/esaro/5481 early childhood development.html)

World Bank. 2010. The Education System in Swaziland: Training and skills development for shared growth and competitiveness.http://siteresources.worldbank.org/EDUCATION/Resources/2782001099079877269/education system in Swaziland.pdf [Accessed 3 Aug. 2015].

World Bank. 2014a. Botswana - Skills for competitiveness and economic growth. http://documents.worldbank.org/curated/en/2014/01/22670017/botswana-skills-competitivenesseconomic-growth [Accessed 3 Aug. 2015].

World Bank. 2014b. Swaziland: building skills for high-priority sectors. http://documents. worldbank.org/curated/en/2014/04/19654933/swaziland-building-skills-high-priority-sectors [Accessed 3 Aug. 2015].

World Data Bank. 2015. Education Statistics. http://databank.worldbank.org/ data/reports.aspx?source=education-statistics- -all-indicators [Accessed 8 Aug. 2015]. 